Early embryonic development, assisted reproductive technologies, and pluripotent stem cell biology in domestic mammals

Hall, Vanessa Jane; Hinrichs, K.; Lazzari, G.; Betts, D. H.; Hyttel, Poul

Published in:

Veterinary Journal

DOI:

10.1016/j.tvjl.2013.05.026

Publication date:

2013

Document version

Peer reviewed version

Citation for published version (APA):

Hall, V. J., Hinrichs, K., Lazzari, G., Betts, D. H., \& Hyttel, P. (2013). Early embryonic development, assisted reproductive technologies, and pluripotent stem cell biology in domestic mammals. Veterinary Journal, 197(2), 128-142. https://doi.org/10.1016/j.tvjl.2013.05.026 
Review

\title{
Early embryonic development, assisted reproductive technologies, and pluripotent stem cell biology in domestic mammals
}

\author{
V. Hall ${ }^{\mathrm{a}, 1}$, K. Hinrichs ${ }^{\mathrm{b}, 1}$, G. Lazzari ${ }^{\mathrm{c}, 1}$, D.H. Betts ${ }^{\mathrm{d}, 1}$, P. Hyttel ${ }^{\mathrm{a}, *}$ \\ ${ }^{a}$ Department of Veterinary Clinical and Animal Sciences, University of Copenhagen, Denmark \\ ${ }^{\mathrm{b}}$ Department of Veterinary Physiology and Pharmacology, Texas AEM University, College Station, TX, USA \\ ${ }^{\mathrm{c}}$ Avantea, Laboratory of Reproductive Technologies, Cremona, Italy \\ ${ }^{\mathrm{d}}$ Department of Physiology and Pharmacology, Schulich School of Medicine and Dentistry, University of Western Ontario, London, ON, Canada
}

\section{A R T I C L E I N F O}

\section{Article history:}

Accepted 4 May 2013

Available online $\mathrm{xxxx}$

\section{Keywords:}

In vitro fertilization

Cloning

Stem cells

Embryos

Oocytes

\begin{abstract}
A B S T R A C T
Over many decades assisted reproductive technologies, including artificial insemination, embryo transfer, in vitro production (IVP) of embryos, cloning by somatic cell nuclear transfer (SCNT), and stem cell culture, have been developed with the aim of refining breeding strategies for improved production and health in animal husbandry. More recently, biomedical applications of these technologies, in particular, SCNT and stem cell culture, have been pursued in domestic mammals in order to create models for human disease and therapy. The following review focuses on presenting important aspects of preimplantation development in cattle, pigs, horses, and dogs. Biological aspects and impact of assisted reproductive technologies including IVP, SCNT, and culture of pluripotent stem cells are also addressed.

(c) 2013 Elsevier Ltd. All rights reserved.
\end{abstract}

\section{Introduction}

Over the past decade, the landscape for veterinary research in embryo technology and stem cell biology has reshaped dramatically. The initial focus of embryo technology in the domestic animals was to optimize breeding for improvement of production and health. In some countries, such as Brazil and Argentina, embryo technologies have found extended practical application, and large numbers of bovine embryos are produced in vitro and transferred to recipients in these regions. In most parts of the world, however, the breeding-related use of such technologies is quantitatively limited. Investigations on pluripotent embryonic stem cells (ESCs) were initiated more than two decades ago with the aim of using the technology for the production of genetically-modified domestic animals. However, these initial efforts to establish ESCs in the domestic species were soon abandoned, due to the discouraging results and, more importantly, to the ground-breaking discovery that cultured embryonic or even somatic cells could be reprogrammed into totipotency by the egg cytoplasm, allowing for generation of genetically-modified animals by nuclear transfer.

Recently, however, renewed focus on domestic animal embryo technology and stem cell biology has emerged, due to the need for improved biomedical models for human diseases. This development has sparked in-depth research into fundamental aspects of

\footnotetext{
* Corresponding author. Tel.: +45 35332541.

E-mail address: poh@sund.ku.dk (P. Hyttel).

1 These authors contributed equally to this work.
}

developmental and stem cell biology in the larger domestic mammals, and thus, the understanding of molecular and cellular aspects of initial embryology and phenomena such as pluripotency and cell differentiation in these species is exponentially evolving.

The understanding of pre-implantation embryonic development is a key to optimizing the use of domestic animals as models for human disease, e.g. via refinement by genetic modification and establishment of different stem cell tools, as well as for optimizing the use of embryo technologies for breeding and production. The present review is an attempt to analyse current knowledge of the molecular aspects of pre-implantation development in pigs, cattle, horses, and dogs as well as to discuss the significance of this knowledge for the practical refinement and utilization of in vitro production of embryos, cloning by somatic cell nuclear transfer, and pluripotent stem cell culture.

\section{The anatomy of pre-implantation embryonic development in domestic mammals}

Proper maturation of the oocyte to metaphase II is a prerequisite for fertilization and pre-implantation development. In the sow, cow, and mare maturation occurs in the pre-ovulatory follicle within approximately the last 42,24 , and $36 \mathrm{~h}$ before ovulation, respectively. Interestingly, in the dog the oocyte is ovulated with an intact germinal vesicle and completes maturation in the oviduct over a 2-4 day period.

Upon fertilization, major embryonic genome activation, which occurs at the 4-cell stage in pigs and around the 8-cell stage in cat- 


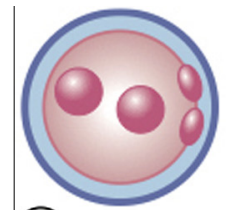

(A) $\downarrow$

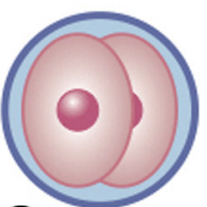

(K)

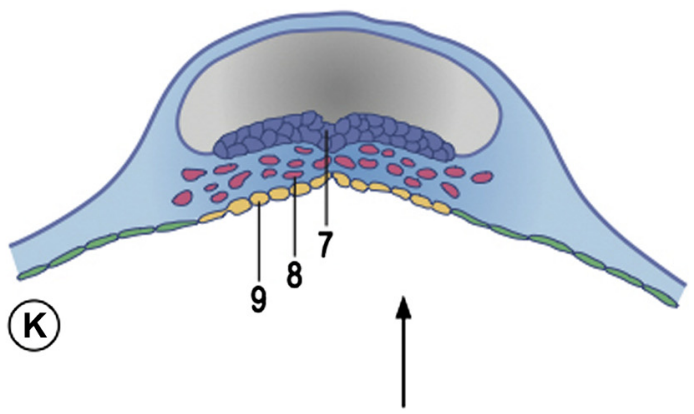

(B)

$\downarrow$

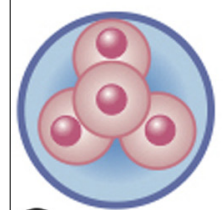

(C)

$\downarrow$

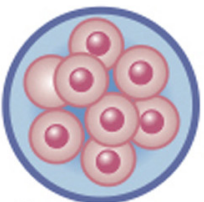

(J)
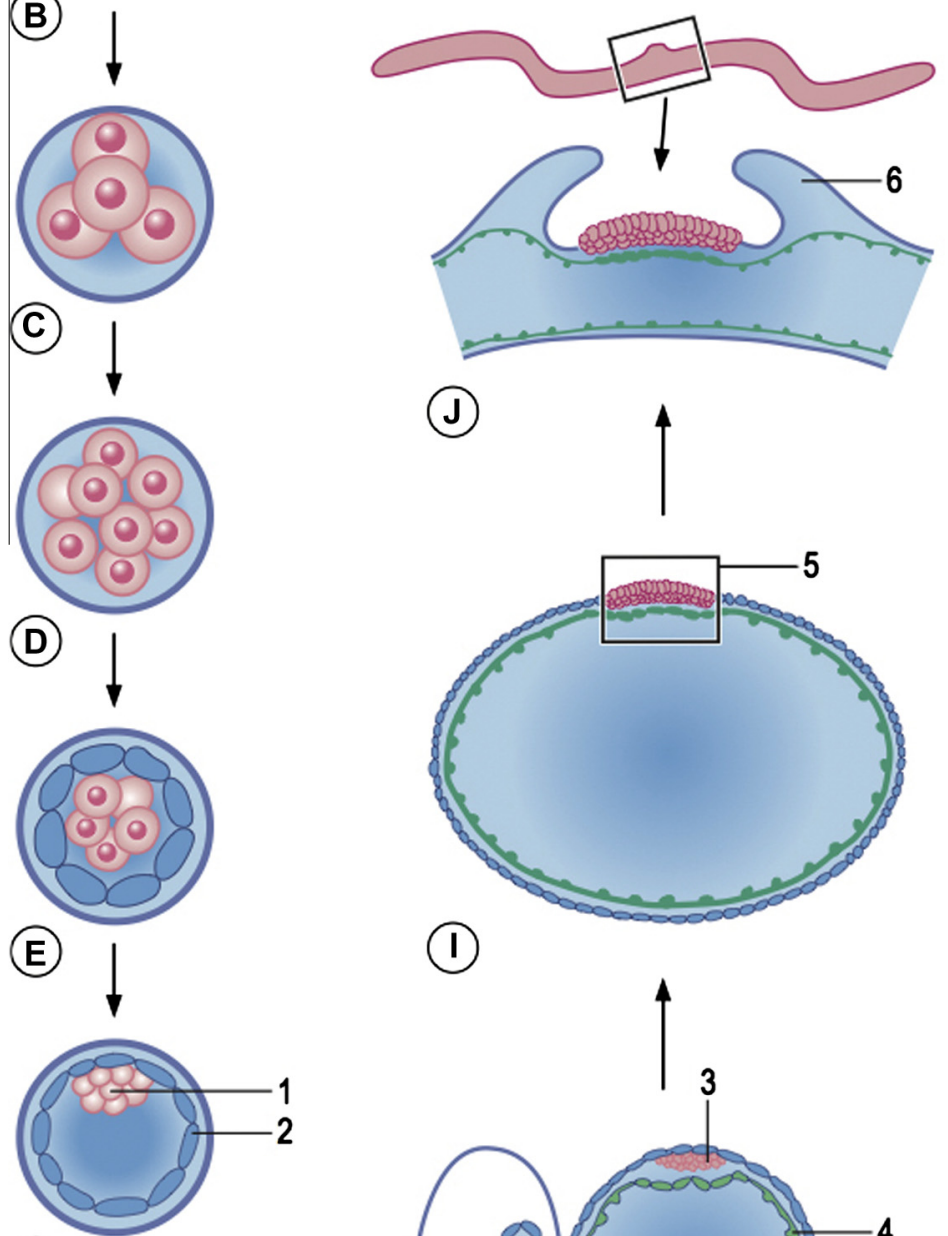

(F)
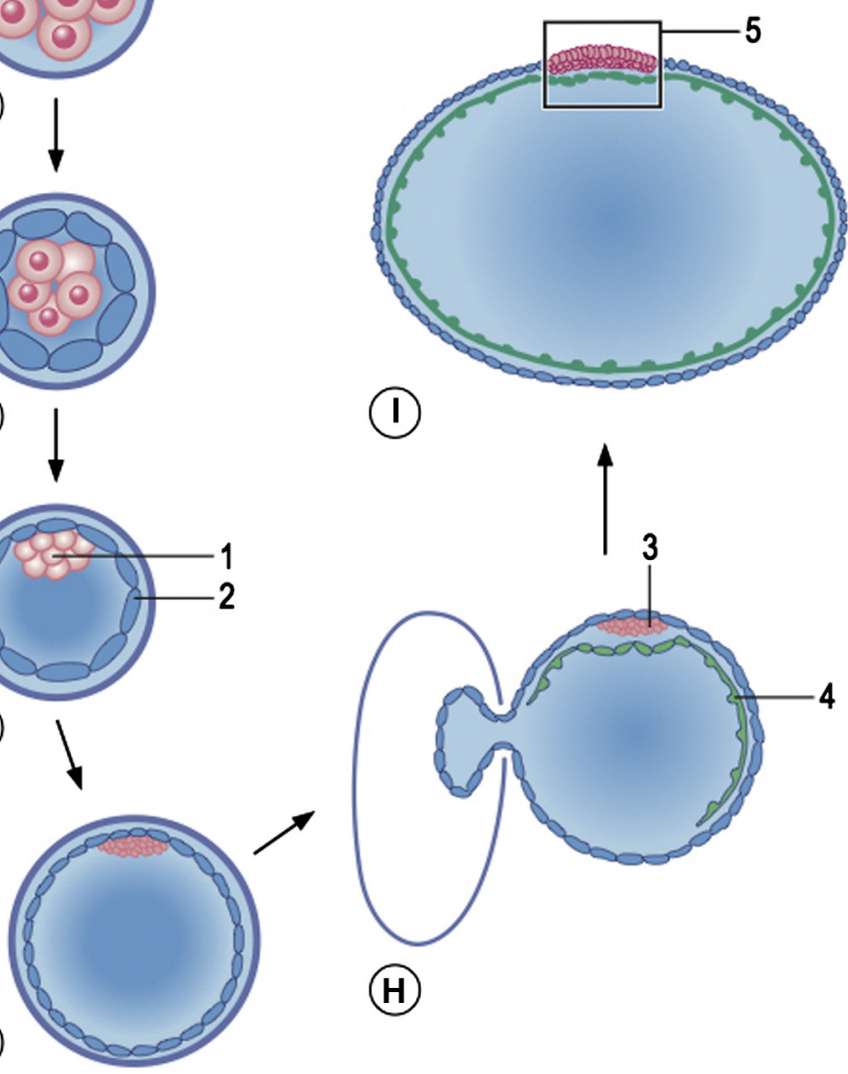

(1)

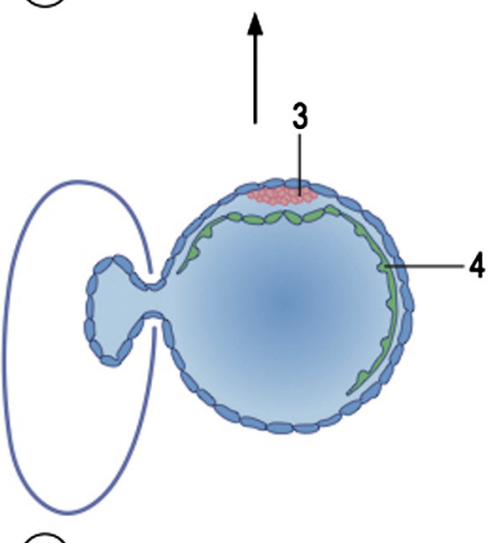

(H)

(G)

Fig. 1. Initial development of the bovine embryo. A: Zygote; B: 2-cell embryo; C: 4-cell embryo; D: Early morula; E: Compact morula; F: Blastocyst; G: Expanded blastocyst; $\mathrm{H}$ : Blastocyst in the process of hatching from the zona pellucida; I: Ovoid blastocyst with embryonic disc; J: Elongated blastocyst; K: Embryonic disc in the process of gastrulation. 1: Inner cell mass; 2: Trophoblast; 3: Epiblast; 4: Hypoblast; 5: Embryonic disc; 6: Amniotic folds; 7: Ectoderm; 8: Mesoderm; 9: Endoderm (from Hyttel et al., 2009). 
tle, horses, and dogs, paves the way for the first lineage segregation into trophoblast and inner cell mass (ICM; Fig. 1). Around the time of hatching from the zona pellucida, the next lineage segregation of the ICM results in the formation of the pluripotent epiblast and the hypoblast, which develops into a flat layer epithelium that gradually covers the inside of the epiblast and trophoblast. The hypoblast is referred to as the primitive endoderm in the mouse; a structure which should not be confused with the definitive endoderm (see later). Along with this process, the trophoblast transforms from being a flattened cell layer to a more cuboidal cell architecture. Subsequently, the polar trophoblast, covering the epiblast, referred to as Rauber's layer, becomes increasingly thin, and, finally, the epiblast penetrates the trophoblast and establishes the embryonic disc, which thus becomes part of the outer lining of the conceptus exposed to the uterine environment.

The following process of gastrulation results in formation of the mesoderm, endoderm (i.e. the definitive endoderm) and ectoderm (Fig. 1): first, the primitive streak develops through cell migration, and cells continuously entering the streak undergo epithelial-mesenchymal transition and ingress to form mesoderm that spreads between the trophoblast/epiblast and hypoblast, and endoderm, which becomes inserted into the sub-epiblast portion of the hypoblast (i.e. definitive endoderm which becomes inserted into primitive endoderm). The fate of the ingressing cells depend on their site of ingression: those ingressing through the anterior streak and primitive node become prechordal plate mesoderm, notochord and endoderm; cells ingressing through 'mid' streak become paraxial mesoderm, and cells ingressing through the posterior streak become extra-embryonic and lateral plate mesoderm (Mikawa et al., 2004).

From the time when the trophoblast gradually becomes lined by extra-embryonic mesoderm on the inside, and becomes continuous with the ectoderm, through the transformation of the noningressing epiblast into ectoderm, the term trophectoderm is applied to this cell compartment. The term trophoblast will, again, be used for those cells of the trophectoderm, which engage in forming the placenta. At the time of gastrulation, chorio-amniotic folds consisting of trophectoderm with an inner lining of extraembryonic mesoderm develop into the amnion. A marked elongation of the conceptus occurs in pigs (to about a meter) and cattle at the time of gastrulation, whereas this phenomenon is not observed in horses and dogs.

\section{Cattle (Bos primigenius taurus and Bos primigenius indicus)}

\section{Molecular regulation of pre-implantation development}

In cattle the major activation of embryonic genome occurs at the 8-cell stage (Fig. 2; Kues et al., 2008) accompanied by changes in chromatin structure such as acetylation of core histones (Memili and First, 1999). At the 32-64-cell stage compaction occurs followed by blastulation at day $7-8$, and hatching occurs at day 8-9 followed by elongation until implantation starts on day 20-21.

Around hatching, the ICM cells differentiate into an inner layer facing the blastocyst cavity, the hypoblast, while the remaining cells form the epiblast (Vejlsted et al., 2006). The polar trophoblast, Rauber's layer, soon degenerates and at the same time gene expression changes of key pluripotency transcription factors POU5F1, SOX2, and NANOG take place (Khan et al., 2012). Contrary to the mouse, this core triad is not confined to the ICM in the early blastocyst, but it is also expressed by the trophoblast together with trophoblast-specific genes CDX2, HAND1, ETS2, and IFN-tau. After formation of the epiblast and hypoblast, however, POU5F1, SOX2, and NANOG expression becomes restricted to the epiblast (Degrelle et al., 2005; Vejlsted et al., 2006).

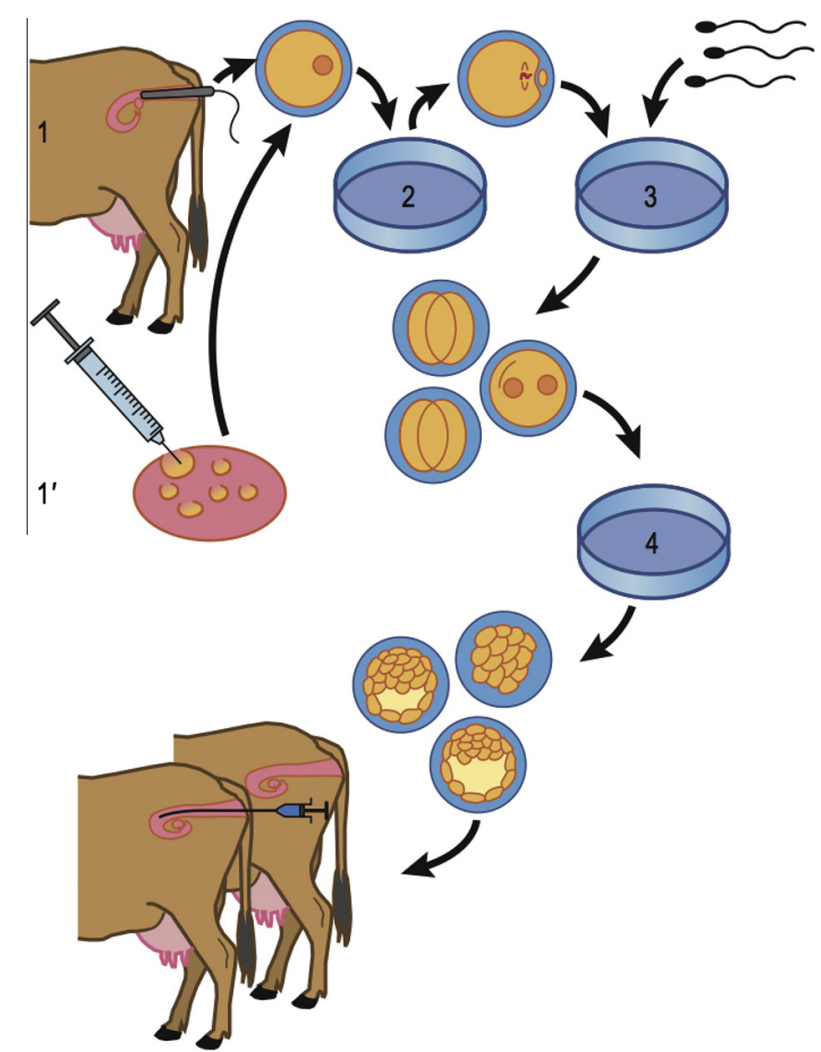

Fig. 2. In vitro production (IVP) of embryos in cattle. Immature oocytes are aspirated from live animals by ultrasound-guided ovum pick up (1) or from abattoir ovaries $\left(1^{\prime}\right)$. Immature oocytes at prophase I are submitted to in vitro maturation (IVM, 2) resulting in progression of meiosis to metaphase II, in vitro fertilization (IVF, 3) resulting in pronucleus formation and initial cleavages, and in vitro culture (IVC, 4) to the morula or blastocyst stage, at which time they can be transferred to recipients (from Hyttel et al., 2009).

\section{In vitro production (IVP) of embryos}

The birth of the first IVF calf derived from in vivo matured oocytes in 1982 (Brackett et al., 1982) and the discovery of heparin as capacitating agent for bull sperm 1986 (Parrish et al., 1986) were the two key events that started an era of intense research efforts for developing efficient bovine in vitro embryo production (IVP) procedures including in vitro maturation (IVM) of the oocyte to the metaphase II, in vitro fertilization (IVF), and subsequent in vitro culture (IVC) of embryos to the blastocyst stage (Fig. 3).

The initial lack of knowledge on embryo requirements was bypassed by temporary in vivo culture in the surrogate sheep oviduct (Galli et al., 2003a, 2003b). At the same time co-culture with oviduct cells, Vero cells, BRL cells, granulosa cells was developed followed by cell-free methods based on synthetic oviductal fluid formulations (SOF; Gardner et al., 1994). While over 30\% blastocyst formation could be achieved in most culture systems, it soon became obvious that quantity did not always match quality (Lonergan et al., 2006) and that serum supplementation was detrimental to embryo/fetal development as the main causal factor of the so-called large offspring syndrome (LOS), characterised by abnormally advanced embryonic and fetal growth, altered gene expression patterns, and high perinatal losses (Young et al., 1998; Lazzari et al., 2002). A large field study demonstrated that the incidence of LOS was greatly reduced by in vitro culture in cell-free and serum-free SOF media (van Wagtendonk-de Leeuw et al., 2000). At present the application of IVP combined with ovum pick up (OPU) from valuable donors is increasing due to developing breeding strategies based on genomics selection using SNP (single 

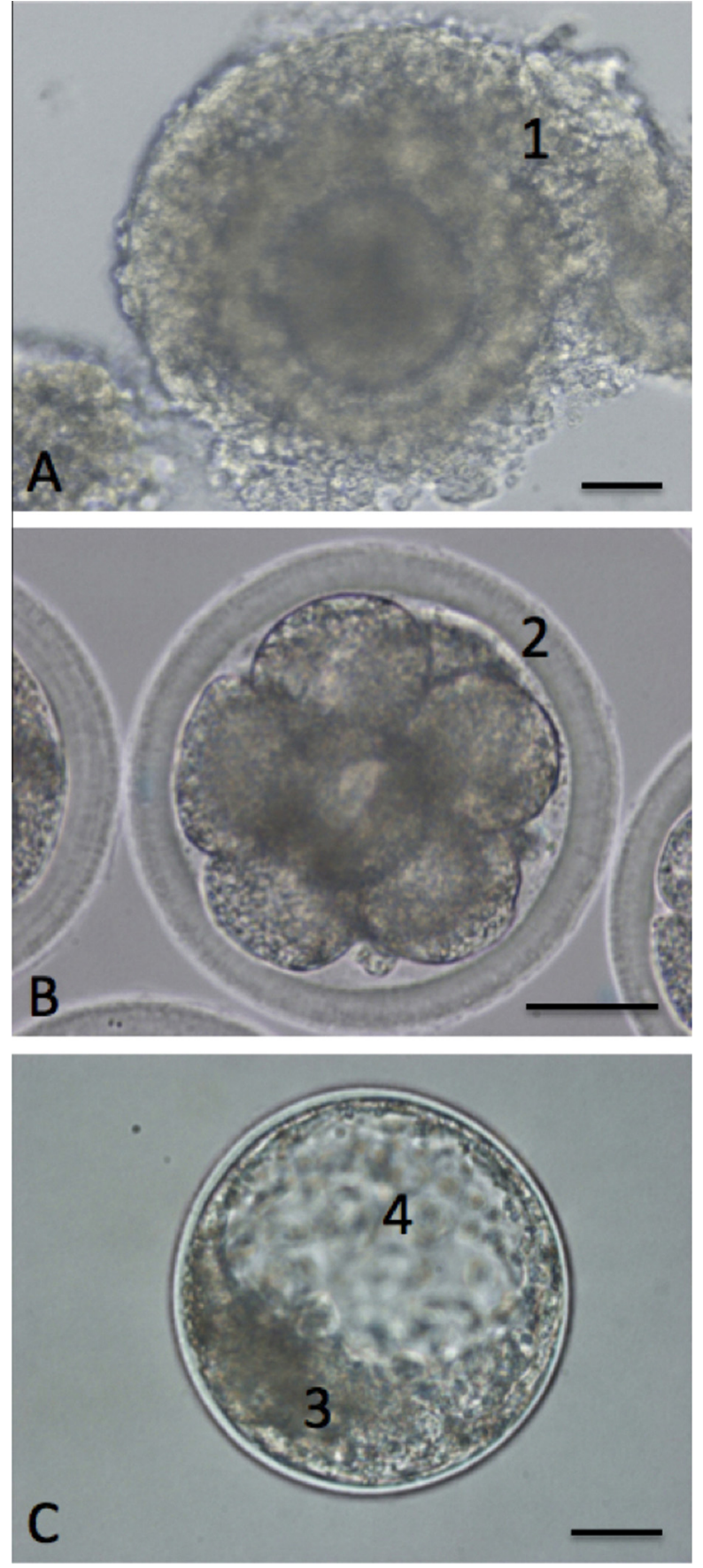

Fig. 3. Bovine in vitro production of embryos. Bovine immature oocyte (A), 8-cell embryo (B), and expanded blastocyst (C). 1: Cumulus cells; 2: Zona pellucida; 3 : Inner cell mass; 4: Blastocyst cavity. Scale bars: $50 \mu \mathrm{m}(\mathrm{A}, \mathrm{B}$, and $\mathrm{C})$.

nucleotide polymorphism) chips, whereby thousands of genetic markers can be screened even on a small embryo biopsy before embryo transfer, with enough precision to anticipate that the need for progeny testing will be dramatically reduced.

\section{Somatic cell nuclear transfer (SCNT)}

In 1986, Willadsen obtained the first cloned sheep using nuclei of embryonic blastomeres for nuclear transfer (Willadsen, 1986). The following year this result was reproduced in cattle (Prather et al., 1987). These achievements sparked a period of intense research in farm animals, which culminated with the birth of 'Dolly'
(Wilmut et al., 1997), the first mammal to be cloned from a nucleus of a somatic cell. Following this event several reports on cattle cloned by SCNT emerged (Vignon et al., 1998; Galli et al., 1999). While cloning originally was applied for enhancement of breeding efficiency, including the rescue of a bovine breed close to extinction (Wells et al., 1998), it soon became a tool for obtaining genetically modified calves (Cibelli et al., 1998a).

The SCNT technology involves the enucleation of a mature oocyte creating a chromosome-free cytoplast, which is typically electrofused with a diploid somatic cell (Fig. 4). This reconstructed embryo is subsequently activated and embarks on embryonic development. The subsequent steps that constitute the technology have been refined with the contribution of dozens of laboratories worldwide over several years. Mostly, enucleated metaphase II oocytes (Campbell et al., 1996; Oback and Wells, 2003) are used as recipient ooplasm, but also enucleated zygotes have been proven suitable to reprogram the transferred nucleus in a more physiological manner as compared to chemical activation of MII cytoplasts (Schurmann et al., 2006).

Quiescent G0 is the preferred cell cycle stage of the donor somatic cells, but also cycling cells (Cibelli et al., 1998a) and blood leukocytes (Galli et al., 1999) have been used as nuclear donors. Technical modifications such as the zona-free manipulation have improved the efficiency of enucleation and fusion (Oback et al., 2003) in several species beside cattle (Lagutina et al., 2007) although development to term is equal to conventional zona-enclosed methods. SCNT is characterised by high pregnancy losses occurring throughout gestation. A comparative embryo transfer study between IVP embryos and cloned embryos derived from embryonic, fetal, and adult cells provided evidence that while the initial pregnancy rate at 21 days is similar (from $55.6 \%$ to $62.7 \%$ ), significant differences are evident at 70 days (49\% vs. $37.3 \%$ vs. $22.5 \%$ vs. $14.3 \%$ for IVP, embryos and embryonic, fetal, and adult cell clones, respectively) and at calving ( $49 \%$ vs. $34.3 \%$ vs. $15 \%$ vs. 6.8\%; Heyman et al., 2002a). For fetal and adult somatic cell cloning the efficiency is also influenced, for yet unclarified mechanisms, by the specific cell line used as source of nuclei (Powell et al., 2004).

Several studies have demonstrated that SCNT embryos present an altered gene expression (Smith et al., 2005) and epigenetic status (Dean et al., 2001), compared with IVP embryos, and the high rate of pregnancy loss has been clinically associated with hydrops and cotyledonary hyperplasia (Heyman et al., 2002b; Everts et al., 2008). These problems are, however, not observed in the offspring of clones, which are normal (Heyman et al., 2004). Because of their poor survival to term, cloned cattle have been subjected to intense studies to demonstrate that the composition of milk and meat from these animals is not different from controls (Heyman et al., 2007) and products from cloned animals or their progeny do not pose any health risk to the consumer.

Embryonic stem cells (ESCs) and induced pluripotent stem cells (iPSCS)

ESCs were isolated for the first time from the murine ICM and cultured and characterized by Evans and Kaufman (1981) and Martin (1981). Recent evidence suggests that there are distinct states of pluripotency (naïve and primed) that differ both morphologically and functionally (De Los Angeles et al., 2012). Naïve murine ESCs (Evans and Kaufman, 1981; Martin, 1981) are derived from the ICM or early epiblast cells, proliferate in culture as packed dome-like colonies, are maintained in the undifferentiated state by LIF-JAK-STAT3 and BMP4 signalling, readily contribute to chimeric embryos, maintain two active $\mathrm{X}$ chromosomes (in female cells) and are relatively resistant to differentiation into primordial germ cells (PGCs) and extra-embryonic lineages (Kuijk et al., 2011).

In contrast, primed pluripotent stem cells have been derived from epiblasts of post-hatching murine blastocysts, are termed 


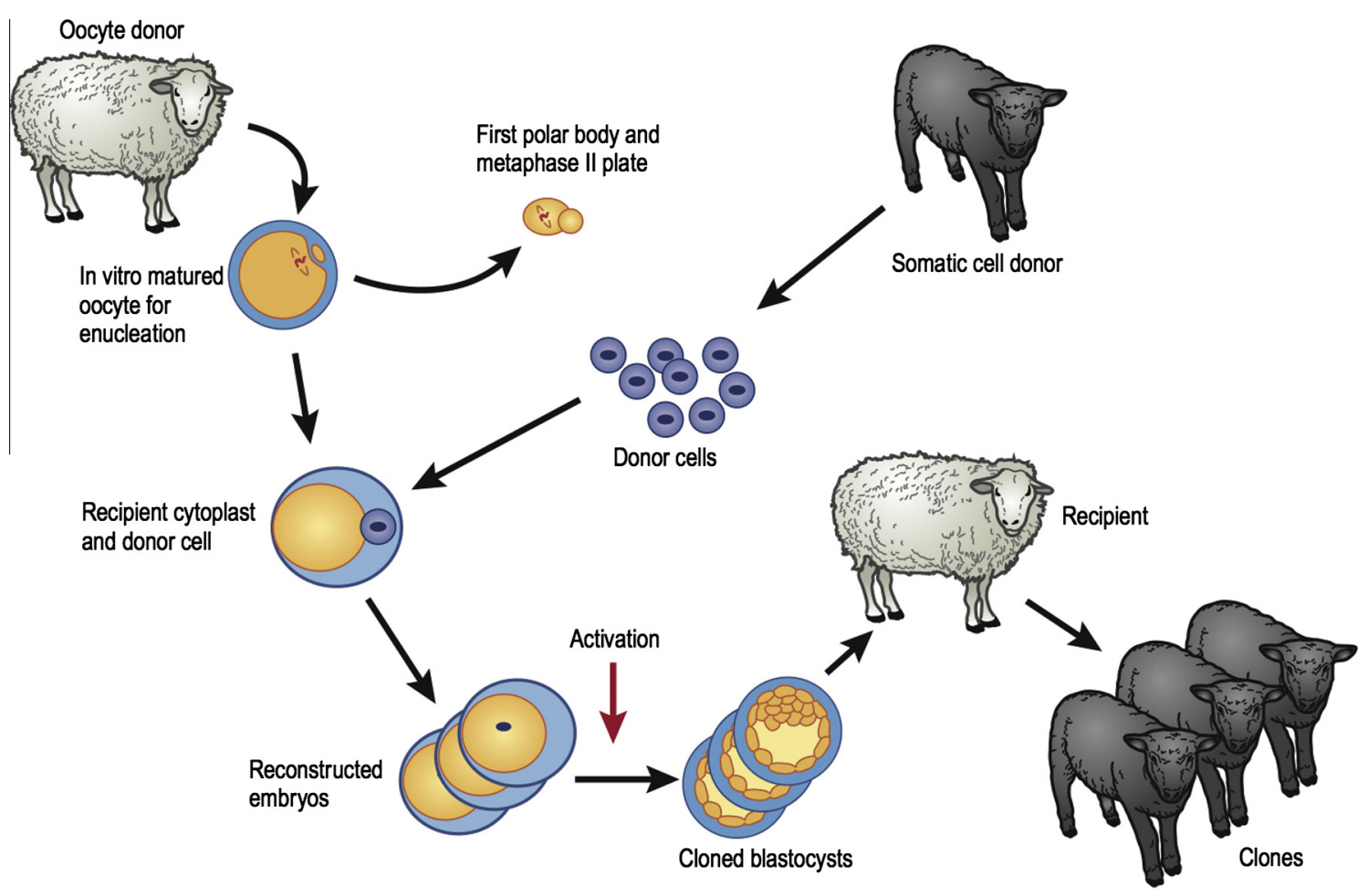

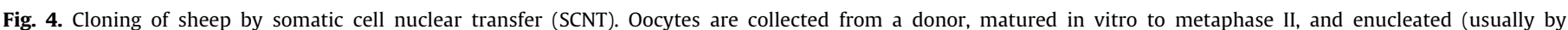

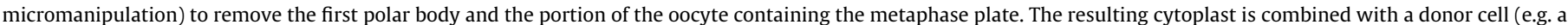

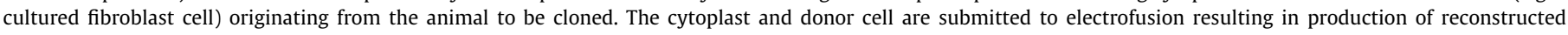

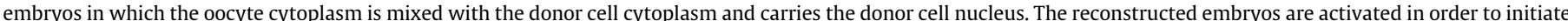

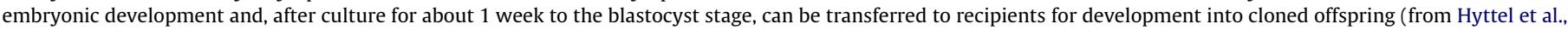
2009).

epiblast stem cells (EpiSCs), are molecularly and epigenetically different from murine ESCs (Brons et al., 2007; Tesar et al., 2007), have a more flattened colony morphology, depend on basic fibroblast growth factor (bFGF) or transforming growth factor alpha (TGF $\alpha$ )/activin signalling for self-renewal, exhibit a limited ability to contribute to chimeras, have undergone X-chromosome inactivation, and readily differentiate into PGC precursors in vitro (Brons et al., 2007). The optimal passaging procedure (single cells trypsinisation vs. disaggregation in clumps) and growth kinetics (14-16 h doubling time in murine ESCs vs. $36 \mathrm{~h}$ in murine EpiSCs) also differ. Moreover, the expression of some pluripotency markers is different: Pou5f1 (also known as Oct4), Nanog, and Sox2 are common, but Klf4, Dppa3, and Zfp42 are specific for murine ESCs. Surprisingly, ESCs derived from human blastocysts exhibit characteristics more like those of murine EpiSCs than their murine ESC counterparts (Thomson et al., 1998).

Most of the published studies on attempting bovine ESC derivation have applied the original mouse protocols (Stice et al., 1996; Cibelli et al., 1998b; Mitalipova et al., 2001; Saito et al., 2003; Keefer et al., 2007) starting from 2-cell embryos (Mitalipova et al., 2001) up to day-12 hatched blastocysts (Gjorret and Maddox-Hyttel, 2005). Colony formation ranges from $14 \%$ to $70 \%$ in the different studies. Some authors report the morula as the most suitable stage (Stice et al., 1996) and others the day- 8 blastocyst (Talbot et al., 1995). There is some controversy with respect to expression of pluripotency markers: according to Saito et al. (2003), presumptive bovine ESCs express alkaline phosphatase (AP), FUT4 (also known as SSEA1), STAT-3, and POU5F1, but are negative for SSEA4, whereas other authors report that they are AP positive and stain for SSEA4, POU5F1, TRA-1-81, and TRA-1-60 (Wang et al., 2005; Munoz et al., 2008) and yet others consider AP staining negative while FUT4, SSEA3, and SSEA4 positive (Stice et al., 1996; Cibelli et al., 1998a, 1998b; Mitalipova et al., 2001).
All reported ESC-like bovine cells do not proliferate long-term, except for a few cases (Mitalipova et al., 2001), and are not capable of contributing significantly to chimeras following morula aggregation (Iwasaki et al., 2000). A recent study (Maruotti et al., 2012) has described the application of human ESC and mouse EpiSC culture protocols, based on bFGF and activin-nodal signalling, to posthatching pre-implantation bovine blastocysts, but again undifferentiated proliferation could not be maintained.

Induced pluripotent stem cells (iPSCs) were first produced in the mouse in 2006, by inserting four transcription factors, including Pou5f1, Sox2, Klf4, and c-Myc into embryonic and adult cells, resulting in a reversion of these cells into a pluripotent state, similar to that observed in the ICM (Takahashi and Yamanaka, 2006). These pluripotent cells can now be created from a multitude of different factors, cell backgrounds, and methods in many different species (Hussein and Nagy, 2012). Derivation of bovine iPSCs was attempted (Huang et al., 2011) using transfection with a polycistronic plasmid containing the complete bovine cDNAs for POU5F1, SOX2, KLF4, and $c-M Y C$, into bovine fibroblasts that were then cultured in presence of specific signalling inhibitors successfully used for mouse and rat ESC culture (Buehr et al., 2008; Ying et al., 2008). Reprogramming efficiency was $0.4 \%$ giving rise to nonproliferative dome-shaped colonies expressing markers of pluripotency, including endogenous iPSC factors, CDH1, DPPA3, NANOG, SOCS3, ZFP42, telomerase, Tra-1-60/81, and SSEA-3/4, but not SSEA-1.

In an another study a lentiviral expression vector (pLentilox 3.7) for human POU5F1 and porcine SOX2, C-MYC, and KLF4 fused with EGFP was transduced into fetal fibroblasts obtaining a reprogramming efficiency of $0.0002-0.0007 \%$ in the presence of LIF and bFGF. The derived colonies resembled human ESCs rather than mouse ESCs, but the transgenes were only partially silenced, indicating incomplete reprogramming (Cao et al., 2012). 


\section{Pig (Sus scrofa domesticus)}

\section{Molecular regulation of pre-implantation development}

The development of the porcine pre-implantation embryo is dependent on a number of key cell signalling events. Initial embryonic cleavage is controlled primarily by innate maternal components carried over from the oocyte in the form of RNA and proteins. However, recent reports suggest that RNA may be introduced via spermatozoa, which could contribute to initial development. Early cleavage events may also be steered or enhanced by external factors present in the oviduct such as oviduct-produced proteins or luminal secreted factors (Buhi et al., 1997). A number of key regulators have been found to act during the initial cleavages including the cell cycle controlling phosphatase cdc25 family (Kim et al., 1999; Anderson et al., 2001) and members of the Src family kinase (SFK) family (Levi et al., 2010). The major embryonic genome activation, which occurs at the 4-cell stage in the pig, paves the way for more complex developmental progression (Fig. 5; Jarrell et al., 1991).

This maternal to embryonic transition marks an important event in development: largely, overcoming transcriptional silencing of the embryo. This event is partly attributable to chromatin remodelling events. Chromatin remodelling genes, including Smar$c a 2$, have been shown to be important in porcine embryonic cleavage (Magnani and Cabot, 2007). A number of histone methyltransferases known to modulate H3K9 (which is associated with transcriptional silencing and cleavage control) have been found to be important in porcine embryonic cleavage (Park et al., 2011). Low expression of the H3K27me3 methylase EZH2 and its co-factors EED and SUZ12 at the 4-cell stage (Gao et al., 2010) suggests a reversal of H3K27me3-dependent transcriptional silencing occurs at this stage. Furthermore, histone H3K4me3 (implicated in gene activation) is thought to play a particular role in the maternal-to-embryonic transition in the pig (Gao et al., 2010).

The first differentiation event, occurring as the blastocyst forms, appears to be also regulated by key genes. Similar to the mouse, ELF5 is expressed primarily in the porcine trophoblast and plays an important role in trophoblast specification (Gao et al., 2011b). $C D X 2$ is another key gene expressed in the porcine trophoblast (Gao et al., 2011a). Interestingly, Eomes, which is another important marker for lineage segregation in the mouse, is dependent on expression of Cdx2 in the trophoblast (Ralston and Rossant, 2008), however, is only expressed in the porcine epiblast and not in the trophoblast (Wu et al., 2010).

Another important gene for ICM specification is probably POU5F1, which is expressed in these cells and becomes exclusively localized in the epiblast during later development (Hall et al., 2009; Gao et al., 2011b). It remains unclear whether the genes NANOG and SOX2 play an important role in ICM specification in the pig. These genes are expressed in the murine ICM, but are only expressed in the pig epiblast (Hall et al., 2009; Wolf et al., 2011). Data on gene regulation during early development are more advanced in the well-studied mouse, but there are some reports which show that both similarities and differences exist between the mouse and the pig.

\section{In vitro production (IVP) of embryos}

The pig has been a particularly difficult species in which to obtain high rates of fertilization and subsequent blastocyst development in vitro. Problems in oocyte cytoplasmic maturation in vitro, high rates of polyspermy, and low embryonic development rates are the major obstacles that still need to be overcome (Gil et al., 2010). The rate of polyspermy has been reported to be over
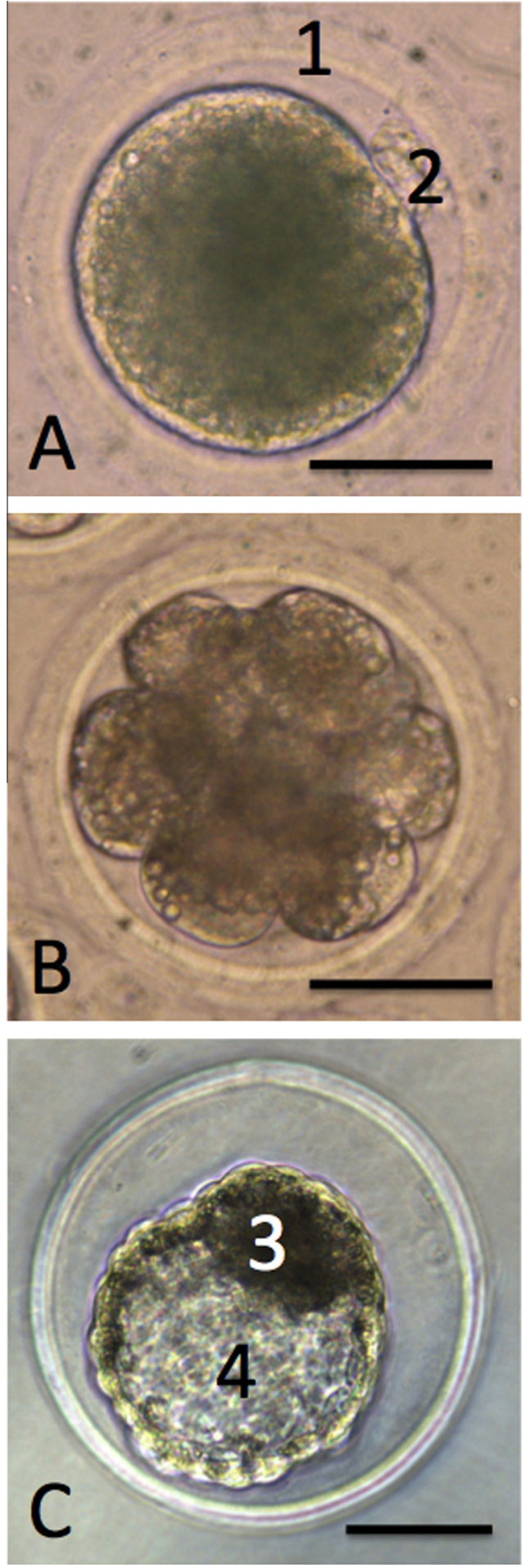

Fig. 5. Porcine oocyte and embryos derived in vivo. Porcine mature oocyte (A), 8cell embryo (B), and blastocyst (C). 1: Zona pellucida; 2: First polar body; 3: Inner cell mass; 4: Blastocyst cavity. Scale bars: $50 \mu \mathrm{m}$ (A, B, and C).

$50 \%$ in some laboratories (Mugnier et al., 2009). Despite these difficulties, IVP blastocyst development rates tend to vary from $30 \%$ to $50 \%$ from monospermically-fertilized oocytes in most laboratories (Gil et al., 2010). Problems with mitochondria migration during IVM have been postulated to be one potential reason for lack of developmental competence (Sun et al., 2001).

The addition of particular components, such as porcine follicular fluid, into the IVM media has been shown to improve the qual- 
ity of porcine IVM (Algriany et al., 2004), as has hormones at particular stages of maturation and insulin-transferrin-selenium ( $\mathrm{Hu}$ et al., 2011). Due to a refinement of techniques, IVM rates now vary from $75 \%$ to $85 \%$ (Gil et al., 2010). One reason for the high rate of polyspermy seen in this species may relate to a delay in the zona reaction, which under normal conditions establishes a prompt barrier to the fertilization by supernumerary spermatozoa (Wang et al., 1998). Reducing the time of exposure of oocytes to the spermatozoa has led to an increase in monospermic fertilization (Gil et al., 2010). A synthetic attempt to harden the zona has also been attempted using an amine-reactive cross linker, which resulted in a 5 -fold increase in monospermic fertilization and an increase in fertilization rate (Coy et al., 2008).

Embryo culture (IVC) has been developed extensively in the pig, and two particularly successful media compositions are used widely today, including NCSU23 and NCSU-37 (Petters and Wells, 1993). Two independent studies have shown that removal of glucose during the first 48-72 h can significantly improve blastocyst development (Abeydeera, 2002; Kikuchi et al., 2002). A chemically defined media has also been developed (PZM5) which appears to be very successful for porcine embryo culture (Yoshioka et al., 2008).

The rate of live offspring resulting from IVP is generally relatively low in the pig compared to the number of transferred IVP embryos, and to date, successful generation of offspring depends on transfer of large numbers of blastocysts or earlier embryos, to produce sufficient litter sizes. A live offspring rate of $11 \%$ to $16 \%$ has been reported from transferred blastocysts when using chemically defined culture media (Kikuchi et al., 2002). The need to transfer relatively large numbers of embryos to achieve even a comparatively low litter size, as well as the lack of stable non-surgical procedures for embryo transfer remain significant obstacles towards the practical implementation of IVP. In contrast, artificial insemination $(\mathrm{AI})$ remains a mainstream method for ART in swine and is used across Europe, the USA, and many other countries worldwide (Day, 2000).

\section{Somatic cell nuclear transfer (SCNT)}

Over the past decade, the efficiency of SCNT has significantly improved due to refinements and simplifications of the cloning technology (Vajta and Callesen, 2012). Development of a zona-free methodology, based on removal of the zona pellucida of the oocyte, combined with the so-called hand-made-cloning, where the oocyte is enucleated by simple hand-held bisectioning, are aspects that have helped to improve blastocyst development of SCNT-produced embryos in the pig (Lagutina et al., 2007; Vajta and Callesen, 2012). Pre-treatment of porcine fibroblasts using Xenopus egg extract has also led to improved in vitro SCNT embryo development (Liu et al., 2011, 2012). As for IVP, vast numbers of SCNT embryos are transferred to produce pregnancies and even relatively-low litter sizes.

A recent report has shown that the average rate of offspring from porcine SCNT embryos using two different pig breeds and two different methods was approximately $7 \%$ of transferred embryos (Schmidt et al., 2010). Perinatal mortality and malformations are unfortunately still major issues that are reported in this species (Schmidt et al., 2010). This is considered to be caused by errors in epigenetic and genetic reprogramming, and has been overcome in some studies by performing an additional re-cloning step (Fujimura et al., 2008; Cao et al., 2012). Despite these considerable setbacks, a staggering number of genetically-modified pigs, serving as potential human disease models, have been produced using SCNT, including animals carrying gene modifications potentially resulting in skin inflammation related to psoriasis (Staunstrup et al., 2012), Alzheimer's disease (Kragh et al., 2009), cystic fibrosis (Welsh et al., 2009; Klymiuk et al., 2012), and diabetes (Renner et al., 2010). Transgenic pig models have also been developed that will aid cancer research and xenotransplantation, such as the recently produced SCID pig (Suzuki et al., 2012). Thus the pig is fast paving the way for an alternative biomedical animal model for varying diseases.

\section{Embryonic stem cells (ESCS) and induced pluripotent stem cells (iPSCs)}

Production of bona fide porcine ESCs remains elusive, which is likely due to inadequate culture conditions (Hall, 2013). Several research groups have attempted to produce porcine ESCs, however these cells only undergo a limited number of cell passages and differentiate spontaneously in culture (Hall, 2008). One research group has successfully been able to culture porcine ICM cells following transduction with the pluripotency genes POU5F1 and KLF4 (Telugu et al., 2011), but transgene-free porcine ESCs remain lacking.

In contrast, iPSCs have been produced in the pig by several different groups (Fig. 6; Ezashi et al., 2012; Kues et al., 2012). These cell lines demonstrate pluripotency and have been shown to contribute towards the formation of chimeras (West et al., 2010) and may even be transmitted through the germline, although this type of transmission was considered rare and combined with perinatal death potentially due to epigenetic aberrations (West et al., 2011). However, unlike their mouse and human counterparts, these cell lines do not silence their inserted transgenes, either during culture or during cell differentiation (Ezashi et al., 2012; Hall et al., 2012). Furthermore, the cells are unable to maintain pluripotency and self-renew when the transgenes are turned off (Wu et al., 2009), indicating that the cells are neither stable in vitro, nor fully reprogrammed.

Problems with both ESCs and iPSCs therefore remain and further research is required in order to determine the exact underlying causes for the continued problems of these cells in culture. Transcriptional profiling of the naïve pluripotent ICM or epiblast may provide some clues as to whether any differences exist in these cells compared to ESCs and iPSCs from mouse and human. Some initial studies have already shown that differences do exist, such as the absence of NANOG and SOX2 in the porcine ICM (Hall et al., 2009). Thus, in vitro cell tools have been developed in the pig,

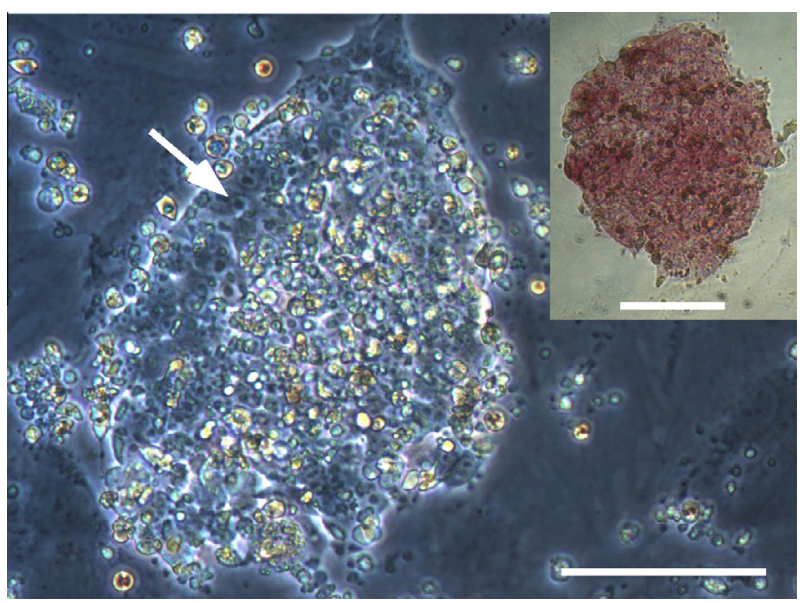

Fig. 6. Porcine induced pluripotent stem cell-like cells. Bright field image of a colony reveals small compact cells containing a large nuclear-to-cytoplasmic ratio with prominent single nucleoli (marked with arrow) and typical high lipid content (refractive yellow portions of colony). Colonies also express alkaline phosphatase (inset image). Colonies are at passage 4 and were grown on mitomycin C-treated mouse embryonic fibroblasts. Cell culture conditions used were KnockOut-DMEM containing $15 \%$ KnockOut Serum, $1 \times$ non-essential amino acids, $1 \times$ glutaMAX, $1 \times$ beta-mercaptoethanol, $1 \times$ penicillin-streptomycin and supplemented with MEK inhibitor PD0325901 and GSK3 inhibitor, CHIR99201. Scale bar: $100 \mu \mathrm{m}$. 
however, further refinement of culture conditions is warranted in order to stabilize iPSC cells and enhance their reprogramming. Such advances may also allow for the development of porcine ESCs in the future.

\section{Horse (Equus ferus caballus)}

\section{Molecular regulation of pre-implantation development}

The time of major embryonic genome activation in the horse embryo appears to be around the 6-cell stage (Brinsko et al., 1995; Grondahl and Hyttel, 1996). The equine blastocyst cavity forms in a multicentric manner, resulting in a loose network of inner cells (Bruyas et al., 1993; Tremoleda et al., 2003; Hinrichs et al., 2007b). The segregation of these inner cells is strikingly different from that of other species: Enders et al. (1993) reported that some cells from this loose inner network form the ICM, and some migrate directly to individually seed the inside of the trophoblast, then spread to form a continuous endodermal layer, resulting in a bilaminar blastocyst.

An acellular capsule forms inside the zona pellucida after entry of the equine embryo into the uterus (Flood et al., 1982; Freeman et al., 1991). The equine capsule is composed of mucin-like glycoproteins produced by the trophectoderm, containing a high proportion of sialic acid (Oriol et al., 1993a, 1993b). Sialic acid transporters and sialyltransferases are upregulated from days 8 to 14 (Klein and Troedsson, 2011).

Guest and Allen (2007) found that FUT4 (previously known as SSEA1), SSEA3, and SSEA4 proteins were expressed in both ICM and trophoblast in day-7 in vivo-recovered horse blastocysts, whereas POU5F1, TRA-1-60, TRA-1-81, and AP activity were localized to the ICM. The ICM cells of $\sim$ Day 10 IVP/transferred embryos expressed significantly higher levels of SOX2 and NANOG than did trophoblast; interestingly, $C D X 2$ expression was present in both cell types (Choi et al., 2009a) and has been reported in the equine embryo proper at days 21-25 (de Mestre et al., 2009). Klein and Troedsson (2011) found that embryonic fibrinogen mRNA increased from day 8 to day 14 , and that fibrinogen was present in the conceptus and environs.

Smits et al. (2011) found five genes upregulated in equine in vivo-derived vs. IVP blastocysts: FABP3, HSP90AA1, ODC1 (previously known as $O D C$ ), $M O B 3$ (previously known as MOBKL3), and $B E X 2$. Heat-shock protein HSPA1A mRNA was higher in IVP vs. in vivo-derived embryos (Mortensen et al., 2010). Choi et al. (2009a) found that production of POU5F1 began at the compacted-morula stage in IVP embryos. POU5F1 protein was limited to the ICM in in vivo-derived embryos but not in IVP embryos, and transfer of IVP embryos to the uterus normalized expression. Similarly, GATA6 protein was present only in hypoblast of day7.5 in vivo-derived embryos, but showed embryo-wide expression in IVP embryos (Desmarais et al., 2011).

At about day 37, specialized equine embryonic trophectoderm cells (chorionic girdle cells) invade into the maternal endometrium, form nests (endometrial cups), and secrete equine chorionic gonadotropin (eCG). Expression of GCM1, a transcription factor found in human syncytiotrophoblast cells, was upregulated in chorionic girdle cells at day 34 (de Mestre et al., 2009). Chorionic girdle cells also showed high expression of the immunoregulatory cytokine, interleukin (IL) 22, which may modulate endometrial response to invasion (Brosnahan et al., 2012).

\section{In vitro production (IVP) of embryos}

Immature equine oocytes may be recovered post mortem, (Hinrichs and Williams, 1997; Hinrichs et al., 2005) or from live mares via transvaginal oocyte aspiration (TVA; Brück et al., 1992; Colleoni et al., 2007; Jacobson et al., 2010). Mature oocytes may be collected by aspiration of the dominant pre-ovulatory follicle after gonadotropin stimulation, via TVA or puncture through the flank (Carnevale and Ginther, 1993; Hinrichs et al., 1998).

Immature oocytes may be held overnight in a modified M199 at room temperature before maturation, with no effect on development (Choi et al., 2006). Maturation is performed effectively in M199 with fetal bovine serum and FSH (Hinrichs et al., 2005; Choi et al., 2007; Ribeiro et al., 2008). The optimum duration of maturation is $24-30 \mathrm{~h}$ and $30-36 \mathrm{~h}$ for oocytes initially having expanded and compact cumuli, respectively. The maturation rate of compact oocytes is lower than that for expanded oocytes ( 20\% vs. $~ 65 \%$ ), but there is no difference in blastocyst development after intracytoplasmic sperm injection (ICSI; Hinrichs et al., 2005).

Standard IVF has not been reliably successful in the horse. Treatment of sperm to induce hyperactivation has resulted in $>60 \%$ fertilization in two studies (McPartlin et al., 2009; Ambruosi et al., 2013). Currently, fertilization in the horse is performed using ICSI. Good blastocyst rates (20\% to $40 \%$ of injected oocytes) are achieved using the Piezo drill (Fig. 7; Hinrichs et al., 2005; Galli et al., 2007; Ribeiro et al., 2008). No exogenous activation is needed.

Low-glucose embryo culture media do not support equine blastocyst formation. Good rates of blastocyst development have been achieved using DMEM/F-12 with fetal bovine serum in a mixed gas atmosphere $\left(5 \% \mathrm{O}_{2}, 5 \% \mathrm{CO}_{2}, 90 \% \mathrm{~N}_{2}\right)$, at $38.2{ }^{\circ} \mathrm{C}$ (Hinrichs et al., 2005; Choi et al., 2007; Ribeiro et al., 2008). Equine embryos develop to the blastocyst stage between days 7 and 10 after ICSI. Pregnancy rates after transfer of IVP blastocysts are 50-70\% (Colleoni et al., 2007; Choi et al., 2011). IVP is currently used clinically in the horse, both in live mares (Colleoni et al., 2007) and post mortem (Hinrichs et al., 2012).

\section{Somatic cell nuclear transfer (SCNT)}

Woods et al. (2003) reported the birth of the first cloned equid, a mule. Viable foals from SCNT have been reported from the laboratory of Dr. Cesare Galli, in Italy (2 foals; Galli et al., 2003a, 2003b; Lagutina et al., 2005), from our laboratory at Texas A\&M (13 foals; Choi et al., 2009b; Choi et al., 2013; Hinrichs et al., 2006, 2007a), and from the laboratory of Dr. Daniel Salamone, in Argentina (2 foals; Gambini et al., 2012). In addition, a company, ViaGen ${ }^{2}$ has announced in the popular press the production of more than 160 viable cloned foals.

The reported blastocyst rate per reconstructed equine oocyte is typically less than $10 \%$. Reconstruction was performed by fusion with zona-free oocytes in Italy (Galli et al., 2003a, 2003b; Lagutina et al., 2005), and this technique, accompanied by aggregation of multiple reconstructed oocytes, was used in Argentina (Gambini et al., 2012). Our laboratory in Texas synchronizes donor cells with roscovitine, injects the cells into enucleated oocytes, and injects sperm extract in addition to using chemical activation (Hinrichs et al., 2006, 2007a; Choi et al., 2009b, 2013). Live foal production per embryo transferred reaches $35 \%$ (Hinrichs et al., 2007a). We reported on the health of cloned foals after birth (Johnson et al., 2010). There was a 50\% incidence of maladjustment, enlarged umbilical remnant, and/or front leg contracture. Two of 14 liveborn foals in this series died within 2 weeks of birth; the other 12 were viable. One of three foals in Italy died within 2 days of birth (Lagutina et al., 2005). The two foals born in Argentina were healthy (Gambini et al., 2012). No reports on foal viability are available from ViaGen.

\footnotetext{
2 See: www.ViaGen.com.
} 

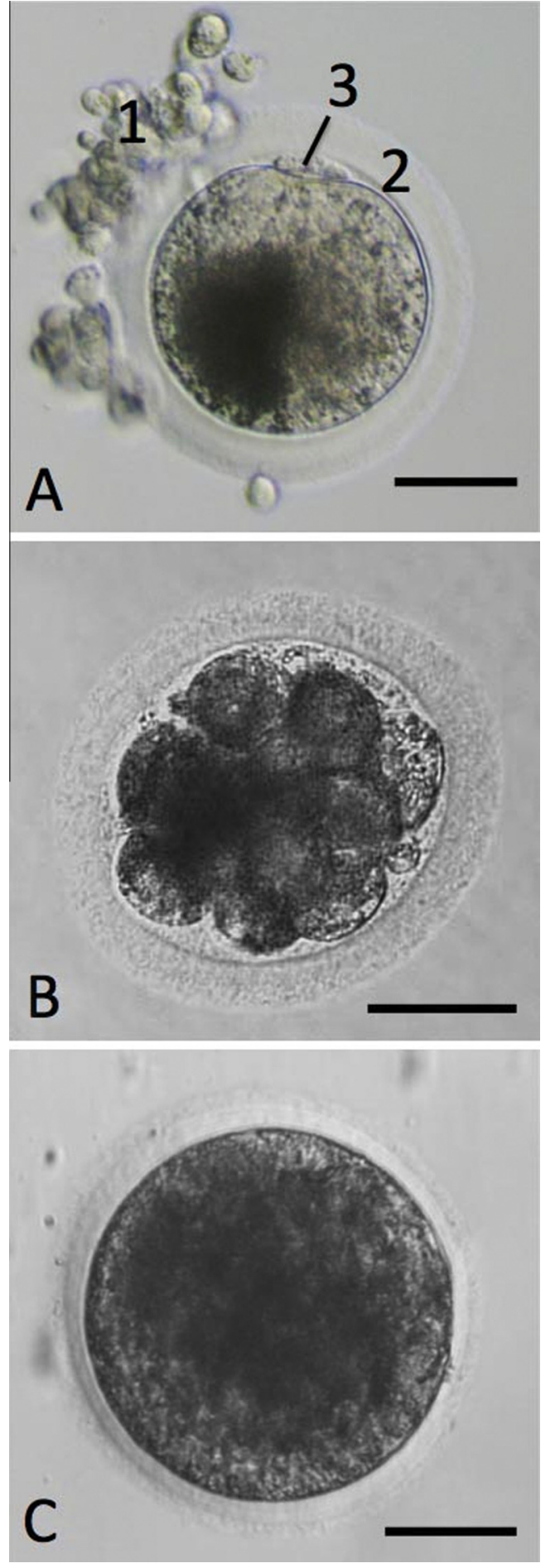

Fig. 7. Equine in vitro production of embryos. Equine in vitro matured oocyte (A), 8cell embryo derived from intracytoplasmic sperm injection (B), and expanded blastocyst (C). Note the lack of a distinct inner cell mass in (C). 1: Cumulus cells; 2 : Zona pellucida; 3: First polar body. Scale bars: $50 \mu \mathrm{m}$ (A, B, and $\mathrm{C})$.

Equine cloning presents an excellent tool for research on genetics vs. environment in a host of equine diseases, but has not yet been utilized for such studies. Commercial equine cloning is performed to preserve valuable genetics, but clones and their offspring are not eligible for registration in most breeds.
Embryonic stem cells (ESC) and induced pluripotent stem cells (iPSC)

Saito et al. (2002) first described the production of equine ESClike cells after microsurgical dissection of ICM from day-8 horse blastocysts. The cells expressed FUT4, STAT3, and POU5F1 and could be differentiated to neural precursor cells. Li et al. (2006) established ESC-like cells after immunosurgical dissection of ICM from day-7 to -8 blastocysts; cells proliferated for up to 28 passages were positive for AP activity, and for FUT4, TRA-1-60, TRA1-81, and POU5F1 protein and mRNA. The cells differentiated into multiple lineages but did not form teratomas when injected into SCID mice. The gene pattern differed from those for mouse and human ES cells, but reflected the pattern of equine ICM cells (Guest and Allen, 2007). Desmarais et al. (2011) produced ESC-like cells from enzymatically-isolated ICM cells of in vivo-derived, parthenogenetic, and SCNT embryos. These authors concluded the cells most likely represented trophoblast stem cells rather than true ESCs.

Nagy et al. (2011) first reported the generation of equine iPSCs, after introducing human POU5F1, SOX2, KLF4, and MYC (also known as $c-M Y C$ ) into equine fetal fibroblasts. The resulting iPSCs expressed AP activity, FUT4, SSEA4, TRA-1-60, TRA-1-81, and NANOG, as well as equine-specific mRNA for POU5F1, NANOG, and KLF4, and formed teratomas. Breton et al. (2013) and Khodadadi et al. (2012) reported production of iPSCs from adult equine fibroblasts; the latter study without use of MYC. Hackett et al. (2012) compared DNA methylation patterns of the NANOG and SOX2 promoter regions and concurrent gene expression of NANOG, SOX2, and POU5F1 in equine iPSCs (Nagy Lab) with those of mesenchymal progenitor cells (commercially marketed as 'stem cells' for treatment of orthopaedic injury in horses). All three pluripotency genes were highly expressed in iPSCs, whereas mesenchymal progenitor cells expressed SOX2 at differentiated levels and did not express NANOG or POU5F1. ESCs and iPSCs have extensive clinical application in the treatment of orthopedic injury in horses, which presents an excellent model for their use in the human athlete; thus, this is an active and relatively well-funded area of research.

\section{Dog (Canis lupus familiaris)}

\section{Molecular regulation of pre-implantation development}

Several characteristics of canine female reproductive physiology and developmental biology, such as a pre-ovulatory follicular luteinization, ovulation of immature germinal vesicle (GV) stage oocytes, and prolonged pre-implantation development/transport in the oviduct are distinctly different from those seen in other mammalian species (Reynaud et al., 2006). These differences may account for the very poor efficiency of IVM, IVF, and IVC in canines (Chastant-Maillard et al., 2010). One unique feature of canine oocytes, zygotes, and embryos is their abundant lipid content that accumulates during follicle growth (Tesoriero, 1981). These lipids, mainly made up of triglycerides and phospholipids, are clearly visible by microscopy and can still be observed in the ICM and trophectoderm of canine blastocysts (Fig. 8) and may be indicative of a unique metabolism that could contribute to their poor development in current in vitro regimes (see below).

Because of these hurdles very limited studies have examined the molecular regulation of canine pre-implantation development. In day-10 flushed canine embryos (morulae and early blastocysts) transcripts for key enzymes of prostaglandin synthesis (COX2), selected growth factors (TGF- $\alpha, I G F-1,-2)$, cytokines $(I L-1 \alpha,-6)$, immune cell receptors (CD4) and matrix-metalloproteinases (MMP-2 and -9) are present (Schafer-Somi et al., 2008). We have detected early lineage markers of the epiblast (POU5F1), trophectoderm 


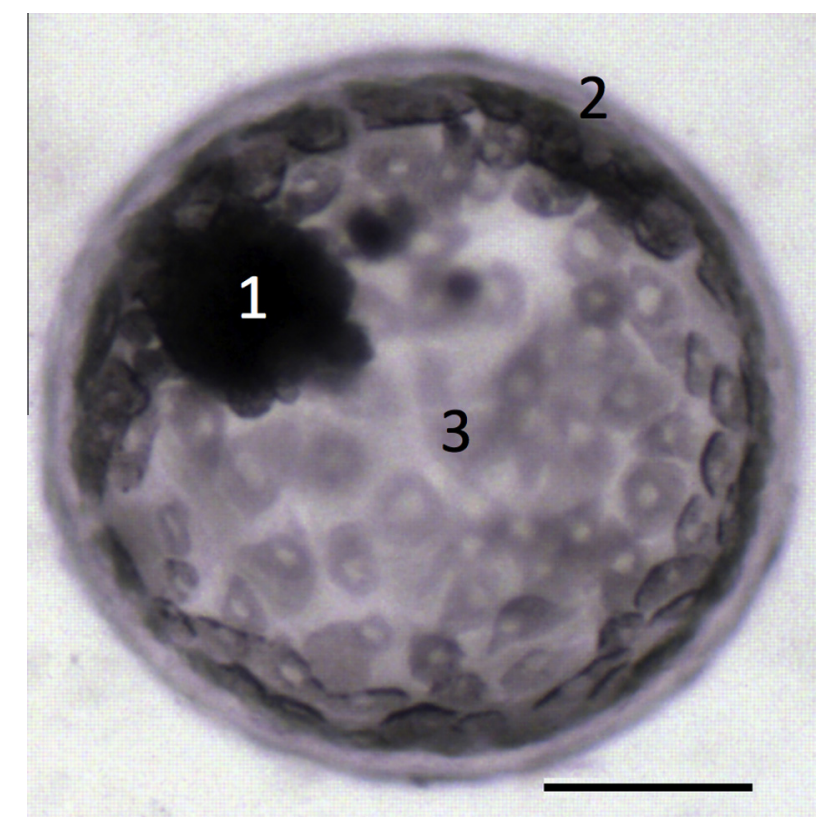

Fig. 8. Expanded canine blastocyst derived in vivo. At 11-15 days following detection of an LH surge canine blastocysts were retrieved from flushed reproductive tracts of inseminated bitches. Note the dark lipid-rich inner cell mass (1). 2 : Zona pellucida; 3: Blastocyst cavity. Scale bar: $100 \mu \mathrm{m}$.

(CDX2), and hypoblast (GATA6) in flushed canine blastocysts (Wilcox et al., 2009). Like other domestic species (Kirchhof et al., 2000), POU5F1 is expressed at diminished levels in the trophectoderm (Wilcox et al., 2009). Clearly, further fundamental research is still required to understand the molecular mechanisms governing oocyte maturation and embryonic development in the dog.

\section{In vitro production (IVP) of embryos}

Although conventional assisted reproductive technologies such as AI and cryopreservation have been highly successful (Thomassen and Farstad, 2009), other advanced technologies have been exceptionally inadequate for obtaining high rates of in vitro embryo development in the dog (Chastant-Maillard et al., 2010). For starters, the IVM rates of canine oocytes are very low compared to results obtained in other domestic species (Otoi et al., 2000; Galli and Lazzari, 2008; Bukowska et al., 2012). Canine oocytes collected from anoestrous ovaries exhibit very low frequencies (10$20 \%$ ) of maturation to the MII stage after 72-96 h of culture (Luvoni et al., 2005; Songsasen and Wildt, 2007), while the IVM rate of oocytes from pre-ovulatory follicles only reaches about 30\% (Yamada et al., 1993).

Compounding this poor IVM is a reduced ability of canine spermatozoa to penetrate (10-50\%) these oocytes in vitro, with only 4$10 \%$ of all oocytes forming two pronuclei after IVF (Mahi and Yanagimachi, 1976; De los Reyes et al., 2009). The poor fertilization is due, in part, to high rates of polyspermy (Saint-Dizier et al., 2001; Hatoya et al., 2006a). ICSI has equally been poor and has not overcome this dual problem of polyspermy and low fertilization ability (Fulton et al., 1998). Although we observed decent in vitro development of in vivo fertilized and flushed canine morulae to the blastocyst stages in SOF medium cultured under 5\% oxygen tensions (Wilcox et al., 2009), a 4- to 8-cell block commonly occurs that contributes to their exceptionally poor in vitro development (Yamada et al., 1992; Otoi et al., 2000; Hori and Tsutsui, 2003; Hatoya et al., 2006a).

\section{Somatic cell nuclear transfer (SCNT)}

While poor rates of IVM and IVF have limited canine ART (Chastant-Maillard et al., 2010), SCNT could be used to improve canine reproduction and produce valuable disease models. Since the birth of 'Snuppy', the first cloned dog (Lee et al., 2005), several breeds of viable cloned puppies have now been produced by SCNT (Jang et al., 2008; Hossein et al., 2009; Kim et al., 2012). Due to the dog's unique reproductive physiology, limitations of canine in vitro embryo technologies (see above) and poor ovulation induction, dog cloning has relied heavily on protocols to surgically collect in vivo matured oocytes by oviduct flushing after predicted natural ovulations (Johnston et al., 2001; Lee et al., 2005) and surgically transfer cloned embryos immediately after reconstruction to spontaneously synchronized recipients (Lee et al., 2005). Nevertheless, over 50 cloned dogs have been reported with an average pregnancy rate of almost $18 \%$ and an average live birth rate of $1.42 \%$ from total number of embryos transferred (Kim et al., 2012).

Cloning can propagate desired canine traits, restore the reproductive ability of old or neutered dogs, and even 'resurrect' a dead pet (Jang et al., 2008; Park et al., 2009). The concept of dog cloning was fostered in 1998 with the multi-million dollar Missyplicity project designed to clone a dog called 'Missy'. Although initially unsuccessful, Missy's clone was born in 2007 as the World's first clone of a family dog. Currently, there are a few companies (e.g. RNL Bio; Perpetuate) that commercially offer canine cloning services and/or will cryobank cells for producing future dog clones when the technology becomes more efficient and cheaper.

Although phenotypic differences have been observed between clones due to stochastic epigenetic reprogramming events (Peat and Reik, 2012), SCNT allows elite characteristics related to nuclear genetic information to be passed on to the clones. Since re-cloned dogs have been recently derived from cells of cloned canines (Hong et al., 2011b; Oh et al., 2011), infinite propagation of these elite abilities, such as the unique scent sniffing capabilities of detection dogs (Park et al., 2009) or even transgenic dogs (Hong et al., 2009; Kim et al., 2011) are theoretically possible. Interspecies SCNT has even been used for preservation of endangered canine species. The grey wolf (Canis lupus), which is considered a threatened species in many countries, was successfully cloned using a wolf somatic cell and a dog oocyte and recipient (Kim et al., 2007; Oh et al., 2008).

Owing to a shared environment and to similarities in physiology, disease presentation, and clinical response at least half of canine diseases are known to have human equivalents making the dog an ideal model for human disorders (Starkey et al., 2005). Although controversial (Varner, 1999; Fiester, 2005), using SCNT to generate genetically modified disease models in dogs looks promising (Jeong et al., 2012; Oh et al., 2012). However, as with other domestic animal clones (Wells, 2005), there have also been some reports of abnormalities in cloned dogs that would currently limit this use (Kim et al., 2009; Hong et al., 2011a). These reports are contentious, however, since there are other published studies showing no adverse effects (Hong et al., 2010; Park et al., 2010). Nevertheless, the challenging reproductive physiological barriers combined with poor ART, low SCNT efficiency, and the high costs associated with these technologies are still limiting factors for achieving translational success with dog cloning.

Embryonic stem cells (ESCS) and induced pluripotent stem cells (iPSCs)

One emerging research field that may contribute to a greater understanding of pre-implantation embryonic development in general and reveal the dog as a model system for developing therapeutic treatments is canine pluripotent stem cells. We were among five research groups to separately derive the first canine 

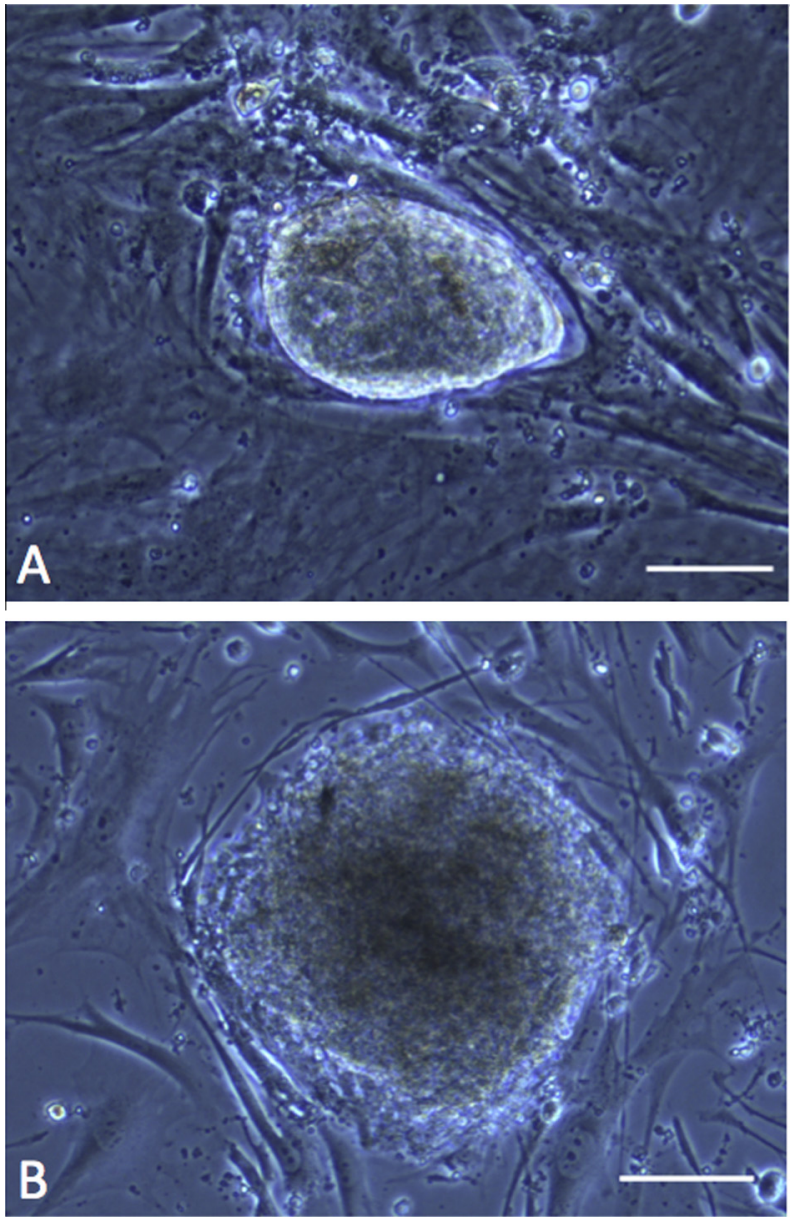

Fig. 9. Naïve (A) and primed (B) canine embryonic stem cell colonies. Canine ESC colonies appear in a primed (hESC-like) pluripotent state when cultured in media contain LIF and bFGF, but morphological changes associated with a more naïve (mESC-like) pluripotent state are observed upon propagation of explanted colonies in media containing just LIF $+2 i$ (glycogen synthase kinase $3 \beta$ and mitogenactivated protein kinase inhibitors). Scale bars: $100 \mu \mathrm{m}$ (A and B).

ESC lines (Hatoya et al., 2006b; Schneider et al., 2007; Hayes et al., 2008; Vaags et al., 2009; Wilcox et al., 2009). All of our characterized lines exhibit prolonged propagation in the undifferentiated state by the expression of established pluripotency markers (e.g. POU5F1, SOX2, and SSEA3). Under culture conditions supporting differentiation, canine ESCs form embryoid bodies that give rise to ectodermal, mesodermal, and endodermal derivatives (Wilcox et al., 2009). Importantly, we have recently established neural progenitors and active neural cell types from our canine ESC lines (Wilcox et al., 2011). Although chimera formation and germ line contribution of canine ESCs have not yet been assessed, some ESC lines have displayed small overt teratoma formation after transplantation into immune compromised mice (Vaags et al., 2009; Wilcox et al., 2009).

Different pluripotent states (naïve vs. primed) likely arise from the species-specific developmental stage from which the cells are derived (Nichols and Smith, 2009) and stabilized by the in vitro conditions they are cultured in (Hanna et al., 2009). Although canine ESCs and canine iPSCs have been derived in LIF-only medium (Hayes et al., 2008; Whitworth et al., 2012), their long term propagation under these conditions have not been demonstrated. Interestingly, it appears that canine ESCs (Vaags et al., 2009; Wilcox et al., 2009) and iPSCs (Luo et al., 2011) require dual-factor culture (LIF and bFGF) to maintain proliferation in the undifferentiated state.
Canine pluripotent stem cells may exist in a stably distinct pluripotent state. However, preliminary studies in our laboratory have shown that canine ESCs are responsive to LIF and $2 i$ (inhibitors of the Mek/Erk and GSK3 pathways) supplemented media with colonies displaying domed-like morphology typical of naïve pluripotency (Fig. 9). Further examination of these unique canine ESCs and iPSCs will allow us to understand to a greater extent the origin of different pluripotent states and will help define/optimize specific culture conditions for their unlimited self-renewal and differentiation into therapeutically relevant cell types to create animal models, stem cell transplantation treatments, and/or as drug screening modalities for human/canine diseases.

\section{Conclusions}

Over the coming years, because of new technological advancements and transcriptome- and proteome-based insight into cellular molecular signalling pathways, further progress in embryo and stem cell culture conditions will be forthcoming. This improved efficiency will increase the safety, efficacy and applicability of assisted reproductive technologies in animal production. However, the greatest impact is expected to be in the area of biomedicine. As with the human stem-cell field, advancements in domestic animal stem cells, and, in particular in iPSCs, will create cellular and animal models of disease that may also be used as drugscreening tools to treat various livestock and companion-animal ailments. In combination with newly-discovered genome editing tools, possible cell-based therapies to regenerate, repair, or even replace damaged or diseased tissue are envisioned in the near future.

\section{Conflict of interest statement}

None of the authors has any financial or personal relationships that could inappropriately influence or bias the content of the paper.

\section{Acknowledgements}

We would like to thank for the financial support from the EU projects EU FP7 PartnErS, PIAP-GA-2008-218205 and PluriSys, HEALTH-2007-B-223485 as well as from the Danish National Advanced Technology Foundation and The Danish Council for Independent Research / Natural Sciences.

\section{References}

Abeydeera, L.R., 2002. In vitro production of embryos in swine. Theriogenology 57, 256-273.

Algriany, O., Bevers, M., Schoevers, E., Colenbrander, B., Dieleman, S., 2004. Follicle size-dependent effects of sow follicular fluid on in vitro cumulus expansion, nuclear maturation and blastocyst formation of sow cumulus oocytes complexes. Theriogenology 62, 1483-1497.

Ambruosi, B., Accogli, G., Douet, C., Canepa, S., Pascal, G., Monget, P., Moros Nicolas, C., Holmskov, U., Mollenhauer, J., Robbe-Masselot, C., Vidal, O., Desantis, S., Goudet, G., 2013. Deleted in malignant brain tumour 1 (DMBT1) is secreted in the oviduct and involved in the mechanism of fertilization in equine and porcine species. Reproduction. http://dx.doi.org/10.1530/REP-13-0007.

Anderson, J.E., Matteri, R.L., Abeydeera, L.R., Day, B.N., Prather, R.S., 2001. Degradation of maternal cdc25c during the maternal to zygotic transition is dependent upon embryonic transcription. Molecular Reproduction and Development 60, 181-188.

Brackett, B.G., Bousquet, D., Boice, M.L., Donawick, W.J., Evans, J.F., Dressel, M.A., 1982. Normal development following in vitro fertilization in the cow. Biology of Reproduction 27, 147-158.

Breton, A., Sharma, R., Diaz, A.C., Parham, A.G., Graham, A., Neil, C., Whitelaw, C.B. Milne, E., Donadeu, F.X., 2013. Derivation and characterization of induced pluripotent stem cells from equine fibroblasts. Stem Cells and Development 22, 611-621. 
Brinsko, S.P., Ball, B.A., Ignotz, G.G., Thomas, P.G.A., Currie, W.B., Ellington, J.E., 1995. Initiation of transcription and nucleologenesis in equine embryos. Molecular Reproduction and Development 42, 298-302.

Brons, I.G., Smithers, L.E., Trotter, M.W., Rugg-Gunn, P., Sun, B., Chuva de Sousa Lopes, S.M., Howlett, S.K., Clarkson, A., Ahrlund-Richter, L., Pedersen, R.A. Vallier, L., 2007. Derivation of pluripotent epiblast stem cells from mammalian embryos. Nature 448, 191-195.

Brosnahan, M.M., Miller, D.C., Adams, M., Antczak, D.F., 2012. IL-22 is expressed by the invasive trophoblast of the equine (Equus caballus) chorionic girdle. Journal of Immunology 188, 4181-4187.

Brück, I., Raun, K., Synnestvedt, B., Greve, T., 1992. Follicle aspiration in the mare using a transvaginal ultrasound-guided technique (short communication). Equine Veterinary Journal 24, 58-59.

Bruyas, J.F., Bezard, J., Lagneaux, D., Palmer, E., 1993. Quantitative analysis of morphological modifications of day 6.5 horse embryos after cryopreservation: Differential effects on inner cell mass and trophoblast cells. Journal of Reproduction and Fertility 99, 15-23.

Buehr, M., Meek, S., Blair, K., Yang, J., Ure, J., Silva, J., McLay, R., Hall, J., Ying, Q.L., Smith, A., 2008. Capture of authentic embryonic stem cells from rat blastocysts. Cell 135, 1287-1298.

Buhi, W.C., Alvarez, I.M., Kouba, A.J., 1997. Oviductal regulation of fertilization and early embryonic development. Journal of Reproduction and Fertility Suppl. 52, 285-300.

Bukowska, D., Kempisty, B., Piotrowska, H., Zawierucha, P., Brussow, K.P., Jaskowski, J.M., Nowicki, M., 2012. The in vitro culture supplements and selected aspects of canine oocytes maturation. Polish Journal of Veterinary Sciences 15, 199-205.

Campbell, K.H., Loi, P., Otaegui, P.J., Wilmut, I., 1996. Cell cycle co-ordination in embryo cloning by nuclear transfer. Reviews of Reproduction 1, 40-46.

Cao, H., Yang, P., Pu, Y., Sun, X., Yin, H., Zhang, Y., Li, Y., Liu, Y., Fang, F., Zhang, Z., Tao, Y., Zhang, X., 2012. Characterization of bovine induced pluripotent stem cells by lentiviral transduction of reprogramming factor fusion proteins. International Journal of Biological Science 8, 498-511.

Carnevale, E.M., Ginther, O.J., 1993. Use of a linear ultrasonic transducer for the transvaginal aspiration and transfer of oocytes in the mare. Journal of Equine Veterinary Science 13, 331-333.

Chastant-Maillard, S., Chebrout, M., Thoumire, S., Saint-Dizier, M., Chodkiewicz, M. Reynaud, K., 2010. Embryo biotechnology in the dog: A review. Reproduction Fertility and Development 22, 1049-1056.

Choi, Y.H., Love, L.B., Varner, D.D., Hinrichs, K., 2006. Holding immature equine oocytes in the absence of meiotic inhibitors: Effect on germinal vesicle chromatin and blastocyst development after intracytoplasmic sperm injection. Theriogenology 66, 955-963.

Choi, Y.H., Love, L.B., Varner, D.D., Hinrichs, K., 2007. Effect of holding technique and culture drop size in individual or group culture on blastocyst development after ICSI of equine oocytes with low meiotic competence. Animal Reproduction Science 102, 38-47.

Choi, Y.H., Harding, H.D., Hartman, D.L., Obermiller, A.D., Kurosaka, S., McLaughlin, K.J., Hinrichs, K., 2009a. The uterine environment modulates trophectodermal POU5F1 levels in equine blastocysts. Reproduction 138, 589-599.

Choi, Y.H., Hartman, D.L., Fissore, R.A., Bedford-Guaus, S.J., Hinrichs, K., 2009b. Effect of sperm extract injection volume, injection of PLCzeta cRNA, and tissue cell line on efficiency of equine nuclear transfer. Cloning and Stem Cells 11, 301-308.

Choi, Y.H., Varner, D.D., Love, C.C., Hartman, D.L., Hinrichs, K., 2011. Production of live foals via intracytoplasmic injection of lyophilized sperm and sperm extract in the horse. Reproduction 142, 529-538.

Choi, Y.H., Norris, J.D., Velez, I.C., Jacobson, C.C., Hartman, D.L., Hinrichs, K., 2013. A viable foal obtained by equine somatic cell nuclear transfer using oocytes recovered from immature follicles of live mares. Theriogenology 79, 791-796.

Cibelli, J.B., Stice, S.L., Golueke, P.J., Kane, J.J., Jerry, J., Blackwell, C., Ponce de Leon, F.A., Robl, J.M., 1998a. Cloned transgenic calves produced from nonquiescent fetal fibroblasts. Science 280, 1256-1258.

Cibelli, J.B., Stice, S.L., Golueke, P.J., Kane, J.J., Jerry, J., Blackwell, C., Ponce de Leon, F.A., Robl, J.M., 1998b. Transgenic bovine chimeric offspring produced from somatic cell-derived stem-like cells. Nature Biotechnology 16, 642-646.

Colleoni, S., Barbacini, S., Necci, D., Duchi, R., Lazzari, G., Galli, C., 2007. Application of ovum pick-up, intracytoplasmic sperm injection and embryo culture in equine practice. In: Proceedings of the American Association of Equine Practitioners, pp. 554-559.

Coy, P., Grullon, L., Canovas, S., Romar, R., Matas, C., Aviles, M., 2008. Hardening of the zona pellucida of unfertilized eggs can reduce polyspermic fertilization in the pig and cow. Reproduction 135, 19-27.

Day, B.N., 2000. Reproductive biotechnologies: Current status in porcine reproduction. Animal Reproduction Science 60-61, 161-172.

De Los Angeles, A., Loh, Y.H., Tesar, P.J., Daley, G.Q., 2012. Accessing naive human pluripotency. Current Opinion in Genetics and Development 22, 272-282.

De los Reyes, M., Palomino, J., de Lange, J., Anguita, C., Barros, C., 2009. In vitro sperm penetration through the zona pellucida of immature and in vitro matured oocytes using fresh, chilled and frozen canine semen. Animal Reproduction Science 110, 37-45.

de Mestre, A.M., Miller, D., Roberson, M.S., Liford, J., Chizmar, L.C., McLaughlin, K.E., Antczak, D.F., 2009. Glial cells missing homologue 1 is induced in differentiating equine chorionic girdle trophoblast cells. Biology of Reproduction 80, 227-234.

Dean, W., Santos, F., Stojkovic, M., Zakhartchenko, V., Walter, J., Wolf, E., Reik, W., 2001. Conservation of methylation reprogramming in mammalian development: Aberrant reprogramming in cloned embryos. Proceedings of the National Academy of Sciences USA 98, 13734-13738.
Degrelle, S.A., Campion, E., Cabau, C., Piumi, F., Reinaud, P., Richard, C., Renard, J.P., Hue, I., 2005. Molecular evidence for a critical period in mural trophoblast development in bovine blastocysts. Developmental Biology 288, 448-460.

Desmarais, J.A., Demers, S.P., Suzuki Jr., J., Laflamme, S., Vincent, P., Laverty, S., Smith, L.C., 2011. Trophoblast stem cell marker gene expression in inner cell mass-derived cells from parthenogenetic equine embryos. Reproduction 141, 321-332.

Enders, A.C., Schlafke, S., Lantz, K.C., Liu, I.K.M., 1993. Endoderm cells of the equine yolk sac from day 7 until formation of the definitive yolk sac placenta. Equine Veterinary Journal Supplement 15, 3-9.

Evans, M.J., Kaufman, M.H., 1981. Establishment in culture of pluripotential cells from mouse embryos. Nature 292, 154-156.

Everts, R.E., Chavatte-Palmer, P., Razzak, A., Hue, I., Green, C.A., Oliveira, R., Vignon, X., Rodriguez-Zas, S.L., Tian, X.C., Yang, X., Renard, J.P., Lewin, H.A., 2008 Aberrant gene expression patterns in placentomes are associated with phenotypically normal and abnormal cattle cloned by somatic cell nuclear transfer. Physiology Genomics 33, 65-77.

Ezashi, T., Telugu, B.P., Roberts, R.M., 2012. Induced pluripotent stem cells from pigs and other ungulate species: An alternative to embryonic stem cells? Reproduction in Domestic Animals (Zuchthygiene) 47, 92-97.

Fiester, A., 2005. Ethical issues in animal cloning. Perspectives in Biological Medicine 48, 328-343.

Flood, P.F., Betteridge, K.J., Diocee, M.S., 1982. Transmission electron microscopy of horse embryos 3-16 days after ovulation. Journal of Reproduction and Fertilility Suppl. 32, 319-327.

Freeman, D.A., Weber, J.A., Geary, R.T., Woods, G.L., 1991. Time of embryo transport through the mare oviduct. Theriogenology 36, 823-830.

Fujimura, T., Murakami, H., Kurome, M., Takahagi, Y., Shigehisa, T., Nagashima, H., 2008. Effects of recloning on the efficiency of production of alpha 1,3galactosyltransferase knockout pigs. The Journal of Reproduction and Development 54, 58-62.

Fulton, R.M., Keskintepe, L., Durrant, B.S., Fayrer-Hosken, R.A., 1998 Intracytoplasmic sperm injection (ICSI) for the treatment of canine infertility. Theriogenology 49, 366

Galli, C., Lazzari, G., 2008. The manipulation of gametes and embryos in farm animals. Reproduction in Domestic Animals 43, 1-7.

Galli, C., Duchi, R., Moor, R.M., Lazzari, G., 1999. Mammalian leukocytes contain all the genetic information necessary for the development of a new individual. Cloning 1, 161-170.

Galli, C., Duchi, R., Crotti, G., Turini, P., Ponderato, N., Colleoni, S., Lagutina, I., Lazzari, G., 2003a. Bovine embryo technologies. Theriogenology 59, 599-616.

Galli, C., Lagutina, I., Crotti, G., Colleoni, S., Turini, P., Ponderato, N., Duchi, R., Lazzari, G., 2003b. A cloned horse born to its dam twin. Nature 424, 635.

Galli, C., Colleoni, S., Duchi, R., Lagutina, I., Lazzari, G., 2007. Developmental competence of equine oocytes and embryos obtained by in vitro procedures ranging from in vitro maturation and ICSI to embryo culture, cryopreservation and somatic cell nuclear transfer. Animal Reproduction Science 98, 39-55.

Gambini, A., Jarazo, J., Olivera, R., Salamone, D.F., 2012. Equine cloning: In vitro and in vivo development of aggregated embryos. Biology of Reproduction 87, 11-19.

Gao, Y., Hyttel, P., Hall, V.J., 2010. Regulation of H3K27me3 and H3K4me3 during early porcine embryonic development. Molecular Reproduction and Development 77, 540-549.

Gao, Y., Hyttel, P., Hall, V.J., 2011a. Dynamic changes in epigenetic marks and gene expression during porcine epiblast specification. Cellular Reprogramming 13, 345-360.

Gao, Y., Jammes, H., Rasmussen, M.A., Oestrup, O., Beaujean, N., Hall, V., Hyttel, P. 2011b. Epigenetic regulation of gene expression in porcine epiblast, hypoblast, trophectoderm and epiblast-derived neural progenitor cells. Epigenetics 6, 1149-1161.

Gardner, D.K., Lane, M., Spitzer, A., Batt, P.A., 1994. Enhanced rates of cleavage and development for sheep zygotes cultured to the blastocyst stage in vitro in the absence of serum and somatic cells: Amino acids, vitamins, and culturing embryos in groups stimulate development. Biology of Reproduction 50, 390400.

Gil, M.A., Cuello, C., Parrilla, I., Vazquez, J.M., Roca, J., Martinez, E.A., 2010. Advances in swine in vitro embryo production technologies. Reproduction in Domestic Animals (Zuchthygiene) 45, 40-48.

Gjorret, J.O., Maddox-Hyttel, P., 2005. Attempts towards derivation and establishment of bovine embryonic stem cell-like cultures. Reproduction, Fertility and Development 17, 113-124.

Grondahl, C., Hyttel, P., 1996. Nucleologenesis and ribonucleic acid synthesis in preimplantation equine embryos. Biology of Reproduction 55, 769-774.

Guest, D.J., Allen, W.R., 2007. Expression of cell-surface antigens and embryonic stem cell pluripotency genes in equine blastocysts. Stem Cells and Development 16, 789-796.

Hackett, C.H., Greve, L., Novakofski, K.D., Fortier, L.A., 2012. Comparison of genespecific DNA methylation patterns in equine induced pluripotent stem cell lines with cells derived from equine adult and fetal tissues. Stem Cells and Development 21, 1803-1811.

Hall, V., 2008. Porcine embryonic stem cells: A possible source for cell replacement therapy. Stem Cell Reviews 4, 275-282.

Hall, V.J., 2013. Early development of the porcine embryo: The importance of cell signaling in development of pluripotent cell lines. Reproduction Fertility and Development 25, 94-102.

Hall, V.J., Christensen, J., Gao, Y., Schmidt, M.H., Hyttel, P., 2009. Porcine pluripotency cell signaling develops from the inner cell mass to the epiblast 
during early development. Developmental Dynamics: An Official Publication of the American Association of Anatomists 238, 2014-2024.

Hall, V.J., Kristensen, M., Rasmussen, M.A., Ujhelly, O., Dinnyes, A., Hyttel, P., 2012. Temporal repression of endogenous pluripotency genes during reprogramming of porcine induced pluripotent stem cells. Cellular Reprogramming 14, 204216.

Hanna, J., Markoulaki, S., Mitalipova, M., Cheng, A.W., Cassady, J.P., Staerk, J., Carey, B.W., Lengner, C.J., Foreman, R., Love, J., Gao, Q., Kim, J., Jaenisch, R., 2009 Metastable pluripotent states in NOD-mouse-derived ESCs. Cell Stem Cell 4 513-524.

Hatoya, S., Sugiyama, Y., Torii, R., Wijewardana, V., Kumagai, D., Sugiura, K., Kida, K. Kawate, N., Tamada, H., Sawada, T., Inaba, T., 2006a. Effect of co-culturing with embryonic fibroblasts on IVM, IVF and IVC of canine oocytes. Theriogenology $66,1083-1090$

Hatoya, S., Torii, R., Kondo, Y., Okuno, T., Kobayashi, K., Wijewardana, V., Kawate, N., Tamada, H., Sawada, T. Kumagai, D., Sugiura, K., Inaba, T., 2006b. Isolation and characterization of embryonic stem-like cells from canine blastocysts. Molecular Reproduction and Development 73, 298-305.

Hayes, B., Fagerlie, S.R., Ramakrishnan, A., Baran, S., Harkey, M., Graf, L., Bar, M. Bendoraite, A., Tewari, M., Torok-Storb, B., 2008. Derivation, characterization, and in vitro differentiation of canine embryonic stem cells. Stem Cells (Dayton, Ohio) 26, 465-473.

Heyman, Y., Chavatte-Palmer, P., LeBourhis, D., Camous, S., Vignon, X., Renard, J.P., 2002a. Frequency and occurrence of late-gestation losses from cattle cloned embryos. Biology of Reproduction 66, 6-13.

Heyman, Y., Richard, C., Rodriguez-Martinez, H., Lazzari, G., Chavatte-Palmer, P. Vignon, X., Galli, C., 2004. Zootechnical performance of cloned cattle and offspring: Preliminary results. Cloning and Stem Cells 6, 111-120.

Heyman, Y., Chavatte-Palmer, P., Fromentin, G., Berthelot, V., Jurie, C., Bas, P., Dubarry, M., Mialot, J.P., Remy, D., Richard, C., Martignat, L., Vignon, X., Renard, J.P., 2007. Quality and safety of bovine clones and their products. Animal 1, 963-972.

Hinrichs, K., Williams, K.A., 1997. Relationships among oocyte-cumulus morphology, follicular atresia, initial chromatin configuration, and oocyte meiotic competence in the horse. Biology of Reproduction 57, 377-384.

Hinrichs, K., Matthews, G.L., Freeman, D.A., Torello, E.M., 1998. Oocyte transfer in mares. Journal of the American Veterinary Medical Association 212, 982-986.

Hinrichs, K., Choi, Y.H., Love, L.B., Varner, D.D., Love, C.C., Walckenaer, B.E., 2005 Chromatin configuration within the germinal vesicle of horse oocytes: Changes post mortem and relationship to meiotic and developmental competence. Biology of Reproduction 72, 1142-1150.

Hinrichs, K., Choi, Y.H., Love, C.C., Chung, Y.G., Varner, D.D., 2006. Production of horse foals via direct injection of roscovitine-treated donor cells and activation by injection of sperm extract. Reproduction 131, 1063-1072.

Hinrichs, K., Choi, Y.H., Varner, D.D., Hartman, D.L., 2007a. Production of cloned horse foals using roscovitine-treated donor cells and activation with sperm extract and/or ionomycin. Reproduction 134, 319-325.

Hinrichs, K., Choi, Y.H., Walckenaer, B.E., Varner, D.D., Hartman, D.L., 2007b. In vitroproduced equine embryos: Production of foals after transfer, assessment by differential staining, and effect of medium calcium concentrations during culture. Theriogenology 68, 521-529.

Hinrichs, K., Choi, Y.H., Norris, J.D., Love, L.B., Bedford-Guaus, S.J., Hartman, D.L. Velez, I.C., 2012. Evaluation of foal production following intracytoplasmic sperm injection and blastocyst culture of oocytes from ovaries collected immediately before euthanasia or after death of mares under field conditions. Journal of the American Veterinary Medical Association 241, 1070-1074.

Hong, S.G., Kim, M.K., Jang, G., Oh, H.J., Park, J.E., Kang, J.T., Koo, O.J., Kim, T., Kwon, M.S. Koo, B.C. and others, 2009. Generation of red fluorescent protein transgenic dogs. Genesis 47, 314-322.

Hong, S.G., Oh, H.J., Park, J.E., Kang, J.T., Kim, M.J., Yoon, J.H., Chang, J.H., Kim, M.K. Jang, G., Lee, B.C., 2010. Serum levels of reproductive hormones and ultrasonographic monitoring of ovarian follicles in female cloned dogs. Journal of Veterinary Medical Science 72, 89-92.

Hong, I.H., Jeong, Y.W., Shin, T., Hyun, S.H., Park, J.K., Ki, M.R., Han, S.Y., Park, S.I., Lee J.H. Lee, E.M., and others, 2011a. Morphological abnormalities, impaired feta development and decrease in myostatin expression following somatic cell nuclear transfer in dogs. Molecular Reproduction and Development 78, 337 346

Hong, S.G., Koo, O.J., Oh, H.J., Park, J.E., Kim, M., Kim, G.A., Park, E.J., Jang, G., Lee, B.C., 2011b. Post mortem re-cloning of a transgenic red fluorescent protein dog. Journal of Veterinary Science 12, 405-407.

Hori, T., Tsutsui, T., 2003. In vitro fertilisation of mature canine ova. Veterinary Record 152, 688-690.

Hossein, M.S., Jeong, Y.W., Park, S.W., Kim, J.J., Lee, E., Ko, K.H., Hyuk, P., Hoon, S.S. Kim, Y.W., Hyun, and others, 2009. Birth of Beagle dogs by somatic cell nuclea transfer. Animal Reproduction Science 114, 404-414.

Hu, J., Ma, X., Bao, J.C., Li, W., Cheng, D., Gao, Z., Lei, A., Yang, C., Wang, H., 2011 Insulin-transferrin-selenium (ITS) improves maturation of porcine oocytes in vitro. Zygote 19, 191-197.

Huang, B., Li, T., Alonso-Gonzalez, L., Gorre, R., Keatley, S., Green, A., Turner, P. Kallingappa, P.K., Verma, V., Oback, B., 2011. A virus-free poly-promoter vector induces pluripotency in quiescent bovine cells under chemically defined conditions of dual kinase inhibition. PLoS One 6, e24501.

Hussein, S.M., Nagy, A.A., 2012. Progress made in the reprogramming field: New factors, new strategies and a new outlook. Current Opinion in Genetics and Development 22, 435-443.
Hyttel, P., Sinowatz, F., Vejlsted, M., 2009. Essentials of Domestic Animal Embryology. Elsevier Science, 455 pp. ISBN:978-0-7020-2899-1.

Iwasaki, S., Campbell, K.H., Galli, C., Akiyama, K., 2000. Production of live calves derived from embryonic stem-like cells aggregated with tetraploid embryos. Biology of Reproduction 62, 470-475.

Jacobson, C.C., Choi, Y.H., Hayden, S.S., Hinrichs, K., 2010. Recovery of mare oocytes on a fixed biweekly schedule, and resulting blastocyst formation after intracytoplasmic sperm injection. Theriogenology 73, 1116-1126.

Jang, G., Hong, S.G., Oh, H.J., Kim, M.K., Park, J.E., Kim, H.J., Kim, D.Y., Lee, B.C., 2008. A cloned toy poodle produced from somatic cells derived from an aged female dog. Theriogenology 69, 556-563.

Jarrell, V.L., Day, B.N., Prather, R.S., 1991. The transition from maternal to zygotic control of development occurs during the 4-cell stage in the domestic pig, Sus scrofa: Quantitative and qualitative aspects of protein synthesis. Biology of Reproduction 44, 62-68.

Jeong, Y.W., Lee, G.S., Kim, J.J., Park, S.W., Ko, K.H., Kang, M., Kim, Y.K., Jung, E.M., Hyun, S.H., Shin, and others, 2012. Establishment of a canine model of human type 2 diabetes mellitus by overexpressing phosphoenolypyruvate carboxykinase. International Journal on Molecular Medicine 30, 321-329.

Johnson, A.K., Clark-Price, S.C., Choi, Y.H., Hartman, D.L., Hinrichs, K., 2010. Physical and clinicopathologic findings in foals derived by use of somatic cell nuclear transfer: 14 cases (2004-2008). Journal of the American Veterinary Medical Association 236, 983-990.

Johnston, S.D., Root Kustritz, M.V., Olson, P.N.S., 2001. The canine estrous cycle. In: Kersey, R., LeMelledo, D. (Eds.), Canine and Feline Theriogenology. WB Saunders Company, Philadeliphia, PA, pp. 16-31.

Keefer, C.L., Pant, D., Blomberg, L., Talbot, N.C., 2007. Challenges and prospects for the establishment of embryonic stem cell lines of domesticated ungulates. Animal Reproduction Science 98, 147-168.

Khan, D.R., Dube, D., Gall, L., Peynot, N., Ruffini, S., Laffont, L., Le Bourhis, D., Degrelle, S., Jouneau, A., Duranthon, V., 2012. Expression of pluripotency master regulators during two key developmental transitions: EGA and early lineage specification in the bovine embryo. PLoS One 7, e34110.

Khodadadi, K., Sumer, H., Pashaiasl, M., Lim, S., Williamson, M., Verma, P.J., 2012. Induction of pluripotency in adult equine fibroblasts without c-MYC. Stem Cells International. http://dx.doi.org/10.1155/2012/429160, Epub.

Kikuchi, K., Onishi, A., Kashiwazaki, N., Iwamoto, M., Noguchi, J., Kaneko, H., Akita, T., Nagai, T., 2002. Successful piglet production after transfer of blastocysts produced by a modified in vitro system. Biology of Reproduction 66, $1033-$ 1041.

Kim, S.H., Li, C., Maller, J.L., 1999. A maternal form of the phosphatase Cdc25A regulates early embryonic cell cycles in Xenopus laevis. Developmental Biology 212, 381-391.

Kim, M.K., Jang, G., Oh, H.J., Yuda, F., Kim, H.J., Hwang, W.S., Hossein, M.S., Kim, J.J., Shin, N.S., Kang, S.K., Lee, B.C., 2007. Endangered wolves cloned from adult somatic cells. Cloning and Stem Cells 9, 130-137.

Kim, S., Park, S.W., Hossein, M.S., Jeong, Y.W., Kim, J.J., Lee, E., Kim, Y.W., Hyun, S.H., Shin, T., Hwang, W.S., 2009. Production of cloned dogs by decreasing the interval between fusion and activation during somatic cell nuclear transfer. Molecular Reproduction and Development 76, 483-489.

Kim, M.J., Oh, H.J., Park, J.E., Kim, G.A., Hong, S.G., Jang, G., Kwon, M.S., Koo, B.C., Kim, T., Kang, S.K., and others, 2011. Generation of transgenic dogs that conditionally express green fluorescent protein. Genesis 49, 472-478.

Kim, M.J., Oh, H.J., Kim, G.A., Park, J.E., Park, E.J., Jang, G., Ra, J.C., Kang, S.K., Lee, B.C., 2012. Lessons learned from cloning dogs. Reproduction in Domestic Animals (Zuchthygiene) 47, 115-119.

Kirchhof, N., Carnwath, J.W., Lemme, E., Anastassiadis, K., Scholer, H., Niemann, H., 2000. Expression pattern of Oct-4 in preimplantation embryos of different species. Biology of Reproduction 63, 1698-1705.

Klein, C., Troedsson, M.H., 2011. Transcriptional profiling of equine conceptuses reveals new aspects of embryo-maternal communication in the horse. Biology of Reproduction 84, 872-885.

Klymiuk, N., Mundhenk, L., Kraehe, K., Wuensch, A., Plog, S., Emrich, D., Langenmayer, M.C., Stehr, M., Holzinger, A., Kroner, C., and others, 2012. Sequential targeting of CFTR by BAC vectors generates a novel pig model of cystic fibrosis. Journal of Molecular Medicine 90, 597-608.

Kragh, P.M., Nielsen, A.L., Li, J., Du, Y., Lin, L., Schmidt, M., Bogh, I.B., Holm, I.E., Jakobsen, J.E., Johansen, and others, 2009. Hemizygous minipigs produced by random gene insertion and handmade cloning express the Alzheimer's disease-causing dominant mutation APPsw. Transgenic Research $18,545-558$.

Kues, W.A., Sudheer, S., Herrmann, D., Carnwath, J.W., Havlicek, V., Besenfelder, U., Lehrach, H., Adjaye, J., Niemann, H., 2008. Genome-wide expression profiling reveals distinct clusters of transcriptional regulation during bovine preimplantation development in vivo. Proceedings of the National Academy of Sciences USA 105, 19768-19773.

Kues, W.A., Herrmann, D., Barg-Kues, B., Meena Haridoss, S., Nowak-Imialek, M., Buchholz, T., Streeck, M., Grebe, A., Grabundzija, I., Merkert, S., and others, 2012. Derivation and characterization of Sleeping Beauty transposon-mediated porcine induced pluripotent stem cells. Stem Cells and Development. http:// dx.doi.org/10.1089/scd.2012.0382.

Kuijk, E.W., Chuva de Sousa Lopes, S.M., Geijsen, N., Macklon, N., Roelen, B.A., 2011. The different shades of mammalian pluripotent stem cells. Human Reproduction Update 17, 254-271.

Lagutina, I., Lazzari, G., Duchi, R., Colleoni, S., Ponderato, N., Turini, P., Crotti, G., Galli, C., 2005. Somatic cell nuclear transfer in horses: Effect of oocyte 
morphology, embryo reconstruction method and donor cell type. Reproduction 130, 559-567.

Lagutina, I., Lazzari, G., Duchi, R., Turini, P., Tessaro, I., Brunetti, D., Colleoni, S., Crotti, G., Galli, C., 2007. Comparative aspects of somatic cell nuclear transfer with conventional and zona-free method in cattle, horse, pig and sheep. Theriogenology 67, 90-98.

Lazzari, G., Wrenzycki, C., Herrmann, D., Duchi, R., Kruip, T., Niemann, H., Galli, C., 2002. Cellular and molecular deviations in bovine in vitro-produced embryos are related to the large offspring syndrome. Biology of Reproduction 67, 767775 .

Lee, B.C., Kim, M.K., Jang, G., Oh, H.J., Yuda, F., Kim, H.J., Hossein, M.S., Kim, J.J., Kang, S.K., Schatten, G., Hwang, W.S., 2005. Dogs cloned from adult somatic cells. Nature 436, 641

Levi, M., Maro, B., Shalgi, R., 2010. Fyn kinase is involved in cleavage furrow ingression during meiosis and mitosis. Reproduction 140, 827-834.

Li, X., Zhou, S.G., Imreh, M.P., hrlund-Richter, L., Allen, W.R., 2006. Horse embryonic stem cell lines from the proliferation of inner cell mass cells. Stem Cells and Development 15, 523-531.

Liu, Y., Ostrup, O., Li, J., Vajta, G., Kragh, P.M., Purup, S., Callesen, H., 2011. Cell colony formation induced by Xenopus egg extract as a marker for improvement of cloned blastocyst formation in the pig. Cellular Reprogramming 13, 521-526.

Liu, Y., Ostrup, O., Li, J., Vajta, G., Lin, L., Kragh, P.M., Purup, S., Hyttel, P., Callesen, H., 2012. Increased blastocyst formation of cloned porcine embryos produced with donor cells pre-treated with Xenopus egg extract and/or digitonin. Zygote 20, 61-66.

Lonergan, P., Fair, T., Corcoran, D., Evans, A.C., 2006. Effect of culture environment on gene expression and developmental characteristics in IVF-derived embryos. Theriogenology 65, 137-152.

Luo, J., Suhr, S.T., Chang, E.A., Wang, K., Ross, P.J., Nelson, L.L., Venta, P.J., Knott, J.G., Cibelli, J.B., 2011. Generation of leukemia inhibitory factor and basic fibroblast growth factor-dependent induced pluripotent stem cells from canine adult somatic cells. Stem Cells and Development 20, 1669-1678.

Luvoni, G.C., Chigioni, S., Allievi, E., Macis, D., 2005. Factors involved in vivo and in vitro maturation of canine oocytes. Theriogenology 63, 41-59.

Magnani, L., Cabot, R.A., 2007. Developmental arrest induced in cleavage stage porcine embryos following microinjection of mRNA encoding Brahma (Smarca 2 ), a chromatin remodeling protein. Molecular Reproduction and Development 74, 1262-1267.

Mahi, C.A., Yanagimachi, R., 1976. Maturation and sperm penetration of canine ovarian oocytes in vitro. Journal of Expimental Zoololy 196, 189-196.

Martin, G.R., 1981. Isolation of a pluripotent cell line from early mouse embryos cultured in medium conditioned by teratocarcinoma stem cells. Proceedings of the National Academy of Sciences USA 78, 7634-7638.

Maruotti, J., Munoz, M., Degrelle, S.A., Gomez, E., Louet, C., Monforte, C.D., de Longchamp, P.H., Brochard, V., Hue, I., Caamano, J.N., Jouneau, A., 2012. Efficient derivation of bovine embryonic stem cells needs more than active core pluripotency factors. Molecular Reproduction and Development 79, 461-477.

McPartlin, L.A., Suarez, S.S., Czaya, C.A., Hinrichs, K., Bedford-Guaus, S.J., 2009. Hyperactivation of stallion sperm is required for successful in vitro fertilization of equine oocytes. Biology of Reproduction 81, 199-206.

Memili, E., First, N.L., 1999. Control of gene expression at the onset of bovine embryonic development. Biology of Reproduction 61, 1198-1207.

Mikawa, T., Poh, A.M., Kelly, K.A., Ishii, Y., Reese, D.E., 2004. Induction and patterning of the primitive streak, an organizing center of gastrulation in the amniote. Developmental Dynamics 229, 422-432.

Mitalipova, M., Beyhan, Z., First, N.L., 2001. Pluripotency of bovine embryonic cell line derived from precompacting embryos. Cloning 3, 59-67.

Mortensen, C.J., Choi, Y.H., Ing, N.H., Kraemer, D.C., Vogelsang, M.M., Hinrichs, K., 2010. Heat shock protein 70 gene expression in equine blastocysts after exposure of oocytes to high temperatures in vitro or in vivo after exercise of donor mares. Theriogenology 74, 374-383.

Mugnier, S., Dell'Aquila, M.E., Pelaez, J., Douet, C., Ambruosi, B., De Santis, T., Lacalandra, G.M., Lebos, C., Sizaret, P.Y., Delaleu, B., and others, 2009. New insights into the mechanisms of fertilization: comparison of the fertilization steps, composition, and structure of the zona pellucida between horses and pigs. Biology of Reproduction 81, 856-870.

Munoz, M., Diez, C., Caamano, J.N., Jouneau, A., Hue, I., Gomez, E., 2008. Embryonic stem cells in cattle. Reproduction in Domestic Animals 43, 32-37.

Nagy, K., Sung, H.K., Zhang, P., Laflamme, S., Vincent, P., Agha-Mohammadi, S., Woltjen, K., Monetti, C., Michael, I.P., Smith, L.C., Nagy, A., 2011. Induced pluripotent stem cell lines derived from equine fibroblasts. Stem Cell Reviews 7 , 693-702.

Nichols, J., Smith, A., 2009. Naive and primed pluripotent states. Cell Stem Cell 4, 487-492.

Oback, B., Wells, D.N., 2003. Cloning cattle. Cloning and Stem Cells 5, 243-256.

Oback, B., Wiersema, A. T., Gaynor, P., Laible, G., Tucker, F. C., Oliver, J. E., Miller, A. L., Troskie, H. E., Wilson, K. L., Forsyth, J. T. and others, 2003. Cloned cattle derived from a novel zona-free embryo reconstruction system. Cloning Stem Cells 5, 312.

Oh, H.J., Kim, M.K., Jang, G., Kim, H.J., Hong, S.G., Park, J.E., Park, K., Park, C., Sohn, S.H., Kim, D.Y., Shin, N.S., Lee, B.C., 2008. Cloning endangered gray wolves (Canis lupus) from somatic cells collected postmortem. Theriogenology 70, 638-647.

Oh, H.J., Park, J.E., Kim, M.J., Hong, S.G., Ra, J.C., Jo, J.Y., Kang, S.K., Jang, G., Lee, B.C., 2011. Recloned dogs derived from adipose stem cells of a transgenic cloned beagle. Theriogenology 75, 1221-1231.
Oh, H.J., Park, J.E., Kim, M.J., Kim, G., Park, E.J., Lim, S.H., Kim, T.W., Cho, J., Jang, G., Lee, B.C., 2012. Neuron-specific expression of the red fluorescence protein in cloned dogs. Reproduction Fertility and Development 24, 128.

Oriol, J.G., Betteridge, K.J., Clarke, A.J., Sharom, F.J., 1993a. Mucin-like glycoproteins in the equine embryonic capsule. Molecular Reproduction and Development 34, 255-265.

Oriol, J.G., Sharom, F.J., Betteridge, K.J., 1993b. Developmentally regulated changes in the glycoproteins of the equine embryonic capsule. Journal of Reproduction and Fertility 99, 653-664.

Otoi, T., Murakami, M., Fujii, M., Tanaka, M., Ooka, A., Une, S., Suzuki, T., 2000 Development of canine oocytes matured and fertilised in vitro. Veterinary Record 146, 52-53.

Park, J.E., Oh, H.J., Hong, S.G., Kang, J.T., Kim, M.J., Kim, D.Y., Ra, J.C., Goo, J., Lee, B.C., 2009. Cloning of cancer sniffing dog by somatic cell nuclear transfer Reproduction Fertility and Development 21, 124-125.

Park, J.E., Kim, M.K., Kang, J.T., Oh, H.J., Hong, S.G., Kim, D.Y., Jang, G., Lee, B.C., 2010 Growth and hematologic characteristics of cloned dogs derived from adult somatic cell nuclear transfer. Cellular Reprogramming 12, 141-150.

Park, K.E., Johnson, C.M., Wang, X., Cabot, R.A., 2011. Differential developmenta requirements for individual histone $\mathrm{H} 3 \mathrm{~K} 9$ methyltransferases in cleavage-stage porcine embryos. Reproduction, Fertility, and Development 23, 551-560.

Parrish, J.J., Susko-Parrish, J.L., Leibfried-Rutledge, M.L., Critser, E.S., Eyestone, W.H., First, N.L., 1986. Bovine in vitro fertilization with frozen-thawed semen. Theriogenology 25, 591-600.

Peat, J.R., Reik, W., 2012. Incomplete methylation reprogramming in SCNT embryos Nature Genetics 44, 965-966.

Petters, R.M., Wells, K.D., 1993. Culture of pig embryos. Journal of Reproduction and Fertility Suppl. 48, 61-73.

Powell, A.M., Talbot, N.C., Wells, K.D., Kerr, D.E., Pursel, V.G., Wall, R.J., 2004. Cell donor influences success of producing cattle by somatic cell nuclear transfer. Biology of Reproduction 71, 210-216.

Prather, R.S., Barnes, F.L., Sims, M.M., Robl, J.M., Eyestone, W.H., First, N.L., 1987 Nuclear transplantation in the bovine embryo: Assessment of donor nuclei and recipient oocyte. Biology of Reproduction 37, 859-866.

Ralston, A., Rossant, J., 2008. Cdx2 acts downstream of cell polarization to cellautonomously promote trophectoderm fate in the early mouse embryo. Developmental Biology 313, 614-629.

Renner, S., Fehlings, C., Herbach, N., Hofmann, A., von Waldthausen, D.C., Kessler, B., Ulrichs, K., Chodnevskaja, I., Moskalenko, V., Amselgruber, W., and others, 2010 Glucose intolerance and reduced proliferation of pancreatic beta-cells in transgenic pigs with impaired glucose-dependent insulinotropic polypeptide function. Diabetes 59, 1228-1238.

Reynaud, K., Fontbonne, A., Marseloo, N., Viaris de Lesegno, C., Saint-Dizier, M. Chastant-Maillard, S., 2006. In vivo canine oocyte maturation, fertilization and early embryogenesis: A review. Theriogenology 66, 1685-1693.

Ribeiro, B.I., Love, L.B., Choi, Y.H., Hinrichs, K., 2008. Transport of equine ovaries for assisted reproduction. Animal Reproduction Science 108, 171-179.

Saint-Dizier, M., Renard, J.P., Chastant-Maillard, S., 2001. Induction of final maturation by sperm penetration in canine oocytes. Reproduction 121, 97-105.

Saito, S., Ugai, H., Sawai, K., Yamamoto, Y., Minamihashi, A., Kurosaka, K., Kobayashi, Y., Murata, T., Obata, Y., Yokoyama, K., 2002. Isolation of embryonic stem-like cells from equine blastocysts and their differentiation in vitro. FEBS Letters 531, 389-396.

Saito, S., Sawai, K., Ugai, H., Moriyasu, S., Minamihashi, A., Yamamoto, Y., Hirayama, H., Kageyama, S., Pan, J., Murata, T. and others, 2003. Generation of cloned calves and transgenic chimeric embryos from bovine embryonic stem-like cells. Biochemical and Biophysical Research Communication 309, 104-113.

Schafer-Somi, S., Beceriklisoy, H.B., Budik, S., Kanca, H., Aksoy, O.A., Polat, B., Cetin, Y., Ay, S.S., Aslan, S., 2008. Expression of genes in the canine pre-implantation uterus and embryo: Implications for an active role of the embryo before and during invasion. Reproduction in Domestic Animals (Zuchthygiene) 43, 656663.

Schmidt, M., Kragh, P.M., Li, J., Du, Y., Lin, L., Liu, Y., Bogh, I.B., Winther, K.D., Vajta, G. Callesen, $H$, 2010. Pregnancies and piglets from large white sow recipients after two transfer methods of cloned and transgenic embryos of different pig breeds. Theriogenology 74, 1233-1240.

Schneider, M.R., Adler, H., Braun, J., Kienzle, B., Wolf, E., Kolb, H.J., 2007. Canine embryo-derived stem cells - Toward clinically relevant animal models for evaluating efficacy and safety of cell therapies. Stem Cells (Dayton, Ohio) 25 1850-1851.

Schurmann, A., Wells, D.N., Oback, B., 2006. Early zygotes are suitable recipients for bovine somatic nuclear transfer and result in cloned offspring. Reproduction $132,839-848$.

Smith, S.L., Everts, R.E., Tian, X.C., Du, F., Sung, L.Y., Rodriguez-Zas, S.L., Jeong, B.S., Renard, J.P., Lewin, H.A., Yang, X., 2005. Global gene expression profiles revea significant nuclear reprogramming by the blastocyst stage after cloning. Proceedings of the National Academy of Sciences USA 102, 17582-17587.

Smits, K., Goossens, K., Van Soom, A., Govaere, J., Hoogewijs, M., Peelman, L.J., 2011. In vivo-derived horse blastocysts show transcriptional upregulation of developmentally important genes compared with in vitro-produced horse blastocysts. Reproduction Fertility Development 23, 364-375.

Songsasen, N., Wildt, D.E., 2007. Oocyte biology and challenges in developing in vitro maturation systems in the domestic dog. Animal Reproduction Science $98,2-22$. 
Starkey, M.P., Scase, T.J., Mellersh, C.S., Murphy, S., 2005. Dogs really are man's bes friend-canine genomics has applications in veterinary and human medicine! Brief Funct Genomic Proteomic 4, 112-128.

Staunstrup, N.H., Madsen, J., Primo, M.N., Li, J., Liu, Y., Kragh, P.M., Li, R., Schmidt, M. Purup, S., Dagnaes-Hansen, F., and others, 2012. Development of transgenic cloned pig models of skin inflammation by DNA transposon-directed ectopic expression of human beta1 and alpha2 integrin. PloS one 7, e36658.

Stice, S.L., Strelchenko, N.S., Keefer, C.L., Matthews, L., 1996. Pluripotent bovine embryonic cell lines direct embryonic development following nuclear transfer. Biology of Reproduction 54, 100-110.

Sun, Q.Y., Wu, G.M., Lai, L., Park, K.W., Cabot, R., Cheong, H.T., Day, B.N., Prather, R.S. Schatten, H., 2001. Translocation of active mitochondria during pig oocyte maturation, fertilization and early embryo development in vitro. Reproduction $122,155-163$

Suzuki, S., Iwamoto, M., Saito, Y., Fuchimoto, D., Sembon, S., Suzuki, M., Mikawa, S. Hashimoto, M., Aoki, Y., Najima, Y., and others, 2012. Il2rg gene-targeted severe combined immunodeficiency pigs. Cell Stem Cell 10, 753-758.

Talbot, N.C., Powell, A.M., Rexroad Jr., C.E., 1995. In vitro pluripotency of epiblasts derived from bovine blastocysts. Molecular Reproduction and Development 42, $35-52$.

Takahashi, K., Yamanaka, S., 2006. Induction of pluripotent stem cells from mouse embryonic and adult fibroblast cultures by defined factors. Cell 126, 663-676.

Telugu, B.P., Ezashi, T., Sinha, S., Alexenko, A.P., Spate, L., Prather, R.S., Roberts, R.M., 2011. Leukemia inhibitory factor (LIF)-dependent, pluripotent stem cells established from inner cell mass of porcine embryos. The Journal of Biological Chemistry 286, 28948-28953.

Tesar, P.J., Chenoweth, J.G., Brook, F.A., Davies, T.J., Evans, E.P., Mack, D.L., Gardner, R.L., McKay, R.D., 2007. New cell lines from mouse epiblast share defining features with human embryonic stem cells. Nature 448, 196-199.

Tesoriero, J.V., 1981. Early ultrastructural changes of developing oocytes in the dog. Journal of Morphology 168, 171-179.

Thomassen, R., Farstad, W., 2009. Artificial insemination in canids: A useful tool in breeding and conservation. Theriogenology 71, 190-199.

Thomson, J.A., Itskovitz-Eldor, J., Shapiro, S.S., Waknitz, M.A., Swiergiel, J.J., Marshall, V.S., Jones, J.M., 1998. Embryonic stem cell lines derived from human blastocysts. Science 282, 1145-1147.

Tremoleda, J.L., Stout, T.A., Lagutina, I., Lazzari, G., Bevers, M.M., Colenbrander, B. Galli, C., 2003. Effects of in vitro production on horse embryo morphology, cytoskeletal characteristics, and blastocyst capsule formation. Biology of Reproduction 69, 1895-1906.

Vaags, A.K., Rosic-Kablar, S., Gartley, C.J., Zheng, Y.Z., Chesney, A., Villagomez, D.A Kruth, S.A., Hough, M.R., 2009. Derivation and characterization of canine embryonic stem cell lines with in vitro and in vivo differentiation potential. Stem Cells 27, 329-340.

Vajta, G., Callesen, H., 2012. Establishment of an efficient somatic cell nuclear transfer system for production of transgenic pigs. Theriogenology 77, 12631274.

van Wagtendonk-de Leeuw, A.M., Mullaart, E., de Roos, A.P., Merton, J.S., den Daas, J.H., Kemp, B., de Ruigh, L., 2000. Effects of different reproduction techniques: A MOET or IVP, on health and welfare of bovine offspring. Theriogenology 53, 575-597.

Varner, G., 1999. Should you clone your dog? An animal rights perspective on somacloning. Animal Welfare 8, 407-420.

Vejlsted, M., Du, Y., Vajta, G., Maddox-Hyttel, P., 2006. Post-hatching development of the porcine and bovine embryo - Defining criteria for expected development in vivo and in vitro. Theriogenology 65, 153-165.

Vignon, X., Chesne, P., Le Bourhis, D., Flechon, J.E., Heyman, Y., Renard, J.P., 1998 Developmental potential of bovine embryos reconstructed from enucleated matured oocytes fused with cultured somatic cells. Comptes Rendus de l'Académie des Sciences - Series III 321, 735-745.

Wang, W.H., Abeydeera, L.R., Prather, R.S., Day, B.N., 1998. Morphologic comparison of ovulated and in vitro-matured porcine oocytes, with particular reference to polyspermy after in vitro fertilization. Molecular Reproduction and Development 49, 308-316.

Wang, L., Duan, E., Sung, L.Y., Jeong, B.S., Yang, X., Tian, X.C., 2005. Generation and characterization of pluripotent stem cells from cloned bovine embryos. Biology of Reproduction 73, 149-155.

Wells, D.N., 2005. Animal cloning: Problems and prospects. Reviews in Science and Technology 24, 251-264.

Wells, D.N., Misica, P.M., Tervit, H.R., Vivanco, W.H., 1998. Adult somatic cell nuclear transfer is used to preserve the last surviving cow of the Enderby Island cattle breed. Reproduction, Fertility, and Development 10, 369-378.

Welsh, M.J., Rogers, C.S., Stoltz, D.A., Meyerholz, D.K., Prather, R.S., 2009. Development of a porcine model of cystic fibrosis. Transactions of the American Clinical and Climatological Association 120, 149-162.

West, F.D., Terlouw, S.L., Kwon, D.J., Mumaw, J.L., Dhara, S.K., Hasneen, K., Dobrinsky, J.R., Stice, S.L., 2010. Porcine induced pluripotent stem cells produce chimeric offspring. Stem Cells and Development 19,1211-1220.

West, F.D., Uhl, E.W., Liu, Y., Stowe, H., Lu, Y., Yu, P., Gallegos-Cardenas, A., Pratt, S.L., Stice, S.L., 2011. Brief report: Chimeric pigs produced from induced pluripotent stem cells demonstrate germline transmission and no evidence of tumor formation in young pigs. Stem Cells 29, 1640-1643.

Whitworth, D.J., Ovchinnikov, D.A., Wolvetang, E.J., 2012. Generation and characterization of LIF-dependent canine induced pluripotent stem cells from adult dermal fibroblasts. Stem Cells and Development 21, 2288-2297.

Wilcox, J.T., Semple, E., Gartley, C., Brisson, B.A., Perrault, S.D., Villagomez, D.A., Tayade, C., Becker, S., Lanza, R., Betts, D.H., 2009. Characterization of canine embryonic stem cell lines derived from different niche microenvironments. Stem Cells and Development 18, 1167-1178.

Wilcox, J.T., Lai, J.K., Semple, E., Brisson, B.A., Gartley, C., Armstrong, J.N., Betts, D.H., 2011. Synaptically-competent neurons derived from canine embryonic stem cells by lineage selection with EGF and Noggin. PLoS One 6, e19768.

Willadsen, S.M., 1986. Nuclear transplantation in sheep embryos. Nature 320, 6365.

Wilmut, I., Schnieke, A.E., McWhir, J., Kind, A.J, Campbell, K.H., 1997. Viable offspring derived from fetal and adult mammalian cells. Nature 385, 810-813.

Wolf, X.A., Serup, P., Hyttel, P., 2011. Three-dimensional localisation of NANOG, POU5F1, and E-CADHERIN in porcine pre- and peri-implantation embryos. Developmental Dynamics: An Official Publication of the American Association of Anatomists 240, 204-210.

Woods, G.L., White, K.L., Vanderwall, D.K., Li, G.P., Aston, K.I., Bunch, T.D., Meerdo, L.N., Pate, B.J., 2003. A mule cloned from fetal cells by nuclear transfer. Science 301, 1063

Wu, Z., Chen, J., Ren, J., Bao, L., Liao, J., Cui, C., Rao, L., Li, H., Gu, Y., Dai, H., and others, 2009. Generation of pig induced pluripotent stem cells with a drug-inducible system. Journal of Molecular Cell Biology 1, 46-54

Wu, G., Gentile, L., Fuchikami, T., Sutter, J., Psathaki, K., Esteves, T.C., Arauzo-Bravo, M.J., Ortmeier, C., Verberk, G., Abe, K., Scholer, H.R., 2010. Initiation of trophectoderm lineage specification in mouse embryos is independent of Cdx2. Development 137, 4159-4169.

Yamada, S., Shimazu, Y., Kawaji, H., Nakazawa, M., Naito, K., Toyoda, Y., 1992. Maturation, fertilization, and development of dog oocytes in vitro. Biology of Reproduction 46, 853-858.

Yamada, S., Shimazu, Y., Kawano, Y., Nakazawa, M., Naito, K., Toyoda, Y., 1993. In vitro maturation and fertilization of preovulatory dog oocytes. Journal of Reproduction and Fertility Suppl. 47, 227-229.

Ying, Q.L., Wray, J., Nichols, J., Batlle-Morera, L., Doble, B., Woodgett, J., Cohen, P., Smith, A., 2008. The ground state of embryonic stem cell self-renewal. Nature $453,519-523$

Yoshioka, K., Suzuki, C., Onishi, A., 2008. Defined system for in vitro production of porcine embryos using a single basic medium. The Journal of Reproduction and Development 54, 208-213.

Young, L.E., Sinclair, K.D., Wilmut, I., 1998. Large offspring syndrome in cattle and sheep. Reviews of Reproduction 3, 155-163. 